\title{
Numerical Investigation on Influence of Two Combined Faults and Its Structure Features on Rock Burst Mechanism
}

\author{
Anye Cao ${ }^{1,2,3, *}$, Yaoqi Liu ${ }^{1, *}$, Siqi Jiang ${ }^{1}$, Qi Hao ${ }^{1}$, Yujie Peng ${ }^{1}$, Xianxi Bai ${ }^{1}$ and Xu Yang ${ }^{4}(\mathbb{D}$ \\ 1 School of Mines, China University of Mining \& Technology, Xuzhou 221116, China; \\ jsq376706577@163.com (S.J.); haoqicumt@163.com (Q.H.); 13955426117@163.com (Y.P.); \\ Baixianxi@163.com (X.B.) \\ 2 Jiangsu Engineering Laboratory of Mine Earthquake Monitoring and Prevention, China University of Mining \\ \& Technology, Xuzhou 221116, China \\ 3 Xuzhou Wushuo Information Co., Ltd., Xuzhou 221116, China \\ 4 School of Computer Science \& Technology, China University of Mining \& Technology, Xuzhou 221116, China; \\ yang_xu@cumt.edu.cn \\ * Correspondence: caoanye@163.com (A.C.); yaoqi_liu@cumt.edu.cn (Y.L.)
}

Citation: Cao, A.; Liu, Y.; Jiang, S.; Hao, Q.; Peng, Y.; Bai, X.; Yang, X. Numerical Investigation on Influence of Two Combined Faults and Its Structure Features on Rock Burst Mechanism. Minerals 2021, 11, 1438. https://doi.org/10.3390/min11121438

Academic Editor: Abbas Taheri

Received: 8 November 2021

Accepted: 16 December 2021

Published: 19 December 2021

Publisher's Note: MDPI stays neutral with regard to jurisdictional claims in published maps and institutional affiliations.

Copyright: (c) 2021 by the authors. Licensee MDPI, Basel, Switzerland. This article is an open access article distributed under the terms and conditions of the Creative Commons Attribution (CC BY) license (https:/ / creativecommons.org/licenses/by/ $4.0 /)$.

\begin{abstract}
With the increase in coal mining depth, engineering geological conditions and the stress environment become more complex. Many rock bursts triggered by two combined faults have been observed in China, but the mechanism is not understood clearly. The focus of this research aims at investigating the influence of two combined faults on rock burst mechanisms. The six types of two combined faults were first introduced, and two cases were utilized to show the effects of two combined faults types on coal mining. The mechanical response of the numerical model with or without combined faults was compared, and a conceptual model was set up to explain the rock burst mechanism triggered by two combined faults. The influence of fault throw, dip, fault pillar width, and mining height on rock burst potential was analyzed. The main control factors of rock burst in six models that combined two faults were identified by an orthogonal experiment. Results show that six combinations of two faults can be identified, including stair-stepping fault, imbricate fault, graben fault, horst fault, back thrust fault, and ramp fault. The particular roof structure near the two combined faults mining preventing longwall face lateral abutment pressure from transferring to deep rock mass leads to stress concentration near the fault areas. Otherwise, a special roof structure causing the lower system stiffness of mining gives rise to the easier gathering of elastic energy in the coal pillars, which makes it easier to trigger a rock burst. There is a nonlinear relationship between fault parameters and static or dynamic load for graben faults mining. The longwall face has the highest rock burst risk when the fault throw is between 6 and $8 \mathrm{~m}$, the fault dip is larger than $65^{\circ}$, the mining height is greater than $6 \mathrm{~m}$, and the coal pillar width is less than $50 \mathrm{~m}$. The stair-stepping, imbricate, horst, and ramp fault compared to the other fault types will produce higher dynamic load stress during longwall retreat. Fault pillar width is the most significant factor for different two combined faults, leading to the rise of static load stress and dynamic proneness.
\end{abstract}

Keywords: two combined faults; classification; rock burst mechanism; main control factor

\section{Introduction}

As a typical dynamic disaster phenomenon, rock bursts have emerged as the most critical issue for underground engineering, which usually leads to casualties, equipment damage, and roadway destruction with the release of lots of elastic energy [1-9]. The statistics of a large number of rock bursts show that the area affected by geological fault structure is more prone to dynamic disasters [10-14]. For example, by the late 1970s, there had been at least a thousand fault-induced rock bursts at the Witwatersrand gold mine in South Africa [15]. In Longfeng Coal Mine, faults induced rock burst 36 times (50 times in total), $62 \%$ of which occurred when the roadway was close to the faults [8]. 3 November 
2011 witnessed that 10 people were killed and 75 were trapped underground in the Qianqiu Coal Mine due to the fault activation [16]. Otherwise, multiple rock bursts triggered by faults were recorded in many other countries, including the USA, Poland, Australia, South Africa, Germany, Russia, and Canada [17-23].

Considerable efforts have been expended to obtain a comprehensive understanding of rock burst mechanisms triggered by faults or fault slipping. Keneti et al. [11] investigated the influence and mechanism of rock burst corresponding to geological discontinuities (e.g., faults, geological contacts, etc.). The nature of a deformation zone and fault rock related to a rock burst in South Africa was investigated by Stewart, et al. [24]. Uskov et al. [23] investigated the relationship between the tectonic features of faults and rock burst risk in the Norilsk Region, Russia. Li, et al. [25] introduced the concept of the fault coal pillar and suggested that fault-induced rock burst be categorized as fault slip, coal pillar instability, and their coupling type. Cai, et al. [26] verified two types of fault rock burst through similar simulation experiments: mining-induced quasi-static stressdominated and seismic-based dynamic stress-dominated. Wang, et al. [27] investigated the stress distribution characteristics and instability mechanism of fault surfaces under mining conditions. However, the present works only are focused on the relationship between fault slip and rock burst. There is less attention paid to combined geological structures, such as combined faults. Recently, severe several rocks bursts triggered by two combined faults have been reported in China, such as "2.22" rock burst in the Xinjulong Coal Mine (four people killed), "8.2" rock burst in the Tangshan Coal Mine (seven people killed and five people injured), "6.9" rock burst in the Longjiapu Coal Mine (nine people killed and 12 people injured), "10.20" rock burst in the Longyun Coal Mine (21 people killed and four people injured), and "3.27" rock burst in the Qianqiu Coal Mine (six people killed and 13 people injured) [28]. However, the influence of two combined faults and its structure features on the rock burst mechanism is not understood. A systematical investigation on the rock burst mechanism caused by two combined faults is indispensable to conduct the targeted prediction and prevention.

The physical experiment is a powerful tool for assessing the rock burst potential. However, due to the limitations of model size, complex mechanical properties of coal and rock mass, and excavation sequence of a longwall face, a large-scale parametric investigation cannot be carried out. In comparison, the numerical technique has proved to be a powerful tool for studying the mechanics of underground rock [29]. A largescale discrete model was established by Wei, et al. [30] to assess the influence of faults on peak abutment stress, the distribution characteristics of strain energy of coal seam, and the energy released by fault slip. An explicit Finite Element Method (FEM) was developed by Manouchehrian and Cai [6] to perform a parametric study with different fault positions, length, and dip relating to the deep tunnel. An FLAC ${ }^{3 D}$ model was built up by Jiang et al. [31] to analyze the influence of fault parameters on fault behavior and the possibility of rock burst induced by fault slip. Therefore, it is accepted that numerical simulation has unique advantages in large-scale excavation simulation and rock burst risk assessment [32,33].

In this paper, a numerical investigation is conducted to understand the rock burst mechanism and parameter-influenced mechanical response triggered by two combined faults. The types of two combined faults were first introduced based on the types of two embedded faults and the movement direction of the upper and lower walls of the faults. Two FLAC ${ }^{3 \mathrm{D}}$ models, i.e., the base model and two combined fault models, were set up to investigate the mechanical response difference between them and the rock burst mechanism triggered by combined faults. Subsequently, a series of parametric tests (including fault throw, dip, mining height, and fault pillar width) were performed to research the influence of different parameters of two combined faults on rock burst potential. In addition, the orthogonal experiment method with four factors and three levels $\left(3^{4}\right)$ was adopted to identify the main control factors of rock burst triggered by combined faults. 


\section{Classification of Two Combined Faults under Mining Background}

\subsection{Classification of Two Combined Faults}

A slip fault is a geological phenomenon characterized by a fracture zone existing between two rock blocks, in which two blocks can slip along the fracture [34]. The angle between the fault plane and horizontal surface (known as the dip) and the direction of slip along the fault are used by earth scientists to classify faults. It is widely accepted that faults could be classified as dip-slip and strike-slip types depending on whether they move along the dip direction or move horizontally. Especially for dip-slip faults, two types are commonly adopted: (1) normal fault-The hanging wall of the fault moves downward relative to the footwall of the fault; (2) thrust fault-The hanging wall of the fault moves upward relative to the footwall of the fault.

However, in reality, a fault does not exist independently in nature, which means that a fault combined with other faults or folds could form new composite structures [35,36]. Particularly for two adjacent faults, several two combined faults types were systematically proposed by HU [35]: The scheme of the different two combined faults is depicted in Figure 1, and the detailed identification is shown in Table 1.

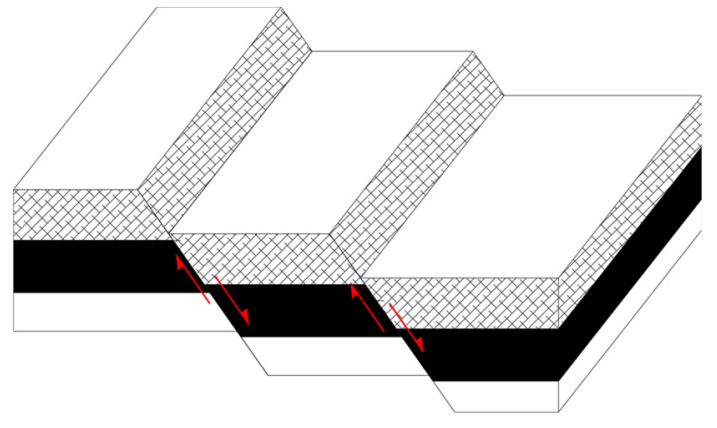

(a)

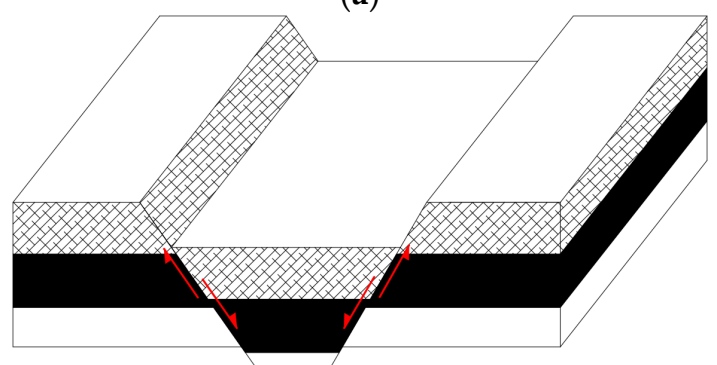

(c)

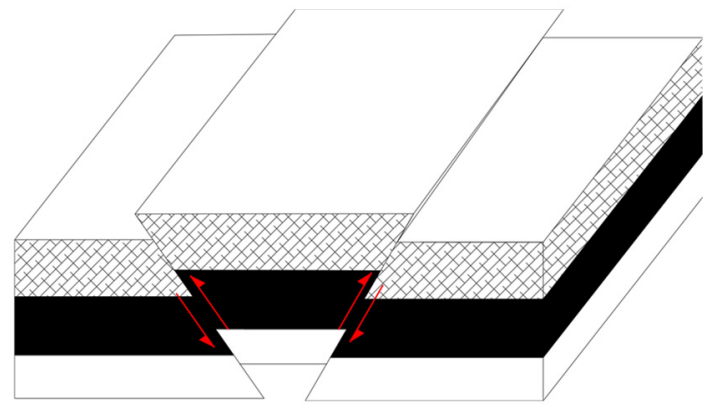

(e)

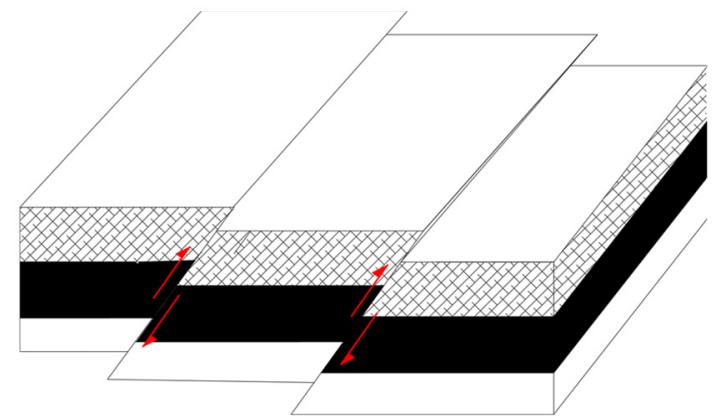

(b)

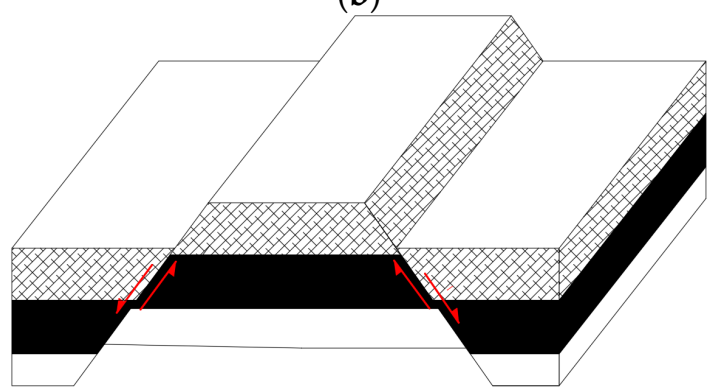

(d)

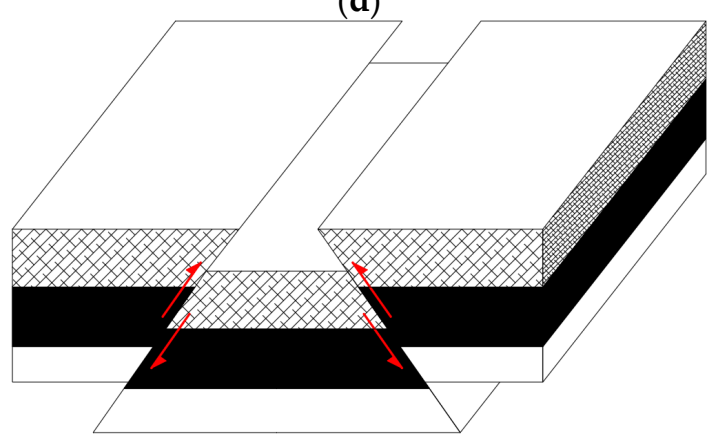

(f)

Figure 1. The scheme of the different two combined faults. (a) Plane view represents stair-stepping fault. (b) Plane view represents imbricate fault. (c) Plane view represents graben fault. (d) Plane view represents horst fault. (e) Plane view represents back thrust fault. (f) Plane view represents ramp fault. The red arrows represent the moving direction of the fault block. The black fill represents coal seams and others represent other sedimentary formations. 
Table 1. The detailed identification of two combined faults (as referred to HU [35]).

\begin{tabular}{|c|c|c|}
\hline Types of Two Combined Faults & Types of Two Embedded Faults & Identification \\
\hline Stair-stepping fault & Two normal faults & $\begin{array}{l}\text { The stair-stepping fault is formed by two parallel } \\
\text { normal faults, the hanging walls of which descend in the } \\
\text { same direction, resembling a staircase. }\end{array}$ \\
\hline Imbricate fault & Two thrust faults & $\begin{array}{l}\text { The imbricate fault is formed by two parallel thrust } \\
\text { faults, the hanging walls of which descend in the same } \\
\text { direction, resembling a roof tile on the house. }\end{array}$ \\
\hline Graben fault & Two normal faults & $\begin{array}{l}\text { The graben fault is composed of two symmetrical and } \\
\text { inclined normal faults with fault walls rising on both } \\
\text { sides and a common descending wall in the middle. }\end{array}$ \\
\hline Horst fault & Two normal faults & $\begin{array}{l}\text { The horst fault is composed of two symmetrically } \\
\text { inclined normal faults with fault walls descending on } \\
\text { both sides and common uplifting walls in the middle. }\end{array}$ \\
\hline Back thrust fault & Two thrust faults & $\begin{array}{l}\text { It is similar to the graben fault, but the back thrust fault } \\
\text { consists of two thrust faults. }\end{array}$ \\
\hline Ramp fault & Two thrust faults & $\begin{array}{l}\text { It is similar to the horst fault, but the ramp fault consists } \\
\text { of two thrust faults. }\end{array}$ \\
\hline
\end{tabular}

\subsection{Influence of Two Combined Faults Types on Coal Mining}

Over the decades, with the coal resources in China rapidly getting exhausted, the mining depth has increased substantially, e.g., the Huafeng Coal Mine, a typical rock burst coal mine in eastern China, has reached $-1300 \mathrm{~m}$ below the surface [37]. It was observed that the increasingly complicated engineering geological conditions had posed a great threat to the safety production of Chinese coal mines. Considerable efforts have been expended to acquire a comprehensive understanding of mechanism of the dynamic failure induced by different factors, including roof rupture [38-40], fault slip [8,26,41], fold structure [42,43], coal pillar [7,44,45], etc. However, more complex geotechnical conditions are characterized by composite geological structures that have been threatening the safety in underground mining.

Recently, especially for the aforesaid two combined faults, several catastrophic accidents have occurred in China. For example, the "2.22" rock burst disaster (occurred on 22 February 2020) of the Xinjulong Coal Mine in Shandong Province, China, trapped a total of 14 people, four of whom died [46]. Meanwhile, the investigation report [46] indicated that the wedge-shaped graben fault structure (GFS) is one of the direct causes of rock burst.

Figure 2a shows the panel layout and seismic events distribution (captured and calculated by seismic monitoring system) from the time the longwall started to retreat until rock burst occurred on longwall (LW) 2305S in the Xinjulong Coal Mine. To facilitate the understanding of roof strata of LW2305S, the A-A cross-section in Figure 2a is shown in Figure 2b, and the stratigraphic column of LW2305S is shown in Figure 2c. Two faults, i.e., FD6 and FD8 run through LW2304S and extend into LW2305S. As shown in Figure 2b, the two faults form a typical GFS. A tremendous amount of seismic events occurred near the LW2305S between the fault FD6 and FD8. Particularly, there were several high-magnitude events that exceeded $10^{5} \mathrm{~J}$, distributing at the area between two faults. It means that the area between the two faults has a significantly higher dynamic disaster risk than the other areas. On the one hand, the existed GFS will lead to specific roof structures (seen in Figure $2 b$ ) and further abnormal roof activity. Moreover, the GFS will reduce mine system stiffness and result in unstable failure of the mine system [6]. 
Similarly, there are stair-stepping faults detected in Xuzhuang Coal Mine, which is a typical burst-prone coal mine in Jiangsu Province, China [8]. As shown in Figure 3a, two faults, the $F_{113}$ fault and $F_{115}$ fault, existed on both sides of the retreat direction of LW7335. Moreover, the dip cross-section of coal mass formed a stair-stepping structure (seen in Figure 3b). Since 2014, the Xuzhuang Coal Mine was equipped with a seismic monitoring system called "SOS" developed by the Central Institute of Mining in Poland to continuously monitor seismicity related to mining activities. Lots of seismic events were detected during the LW7335 retreat between 2018/09/08 and 2019/01/31. As depicted in Figure 3d, many seismic events were distributed near the solid coal area and $F_{115}$ fault rather than the goaf area. An extraordinary phenomenon also indicated that the special roof with stair-stepping faults could lead to an increasingly dynamic disaster potential.

It follows from the above statement that the two combined faults have been a common geological structure and threaten the safety of coal mines. When there is longwall face mining near the faults, the interaction between faults and coal extraction is a key factor leading to the fault reactivation [26]. Otherwise, in order to minimize the disturbance of operation to the faults, longwall panels are usually separated from the faults by fault pillars. Especially for two combined faults (as shown in Figures 2 and 3), the advance of the longwall face is usually consistent with the strike of the fault to reduce the disturbance to the faults. However, in this case, the fault parameters (i.e., throw, dip, and the width of fault pillars) are usually distinct everywhere due to the complex geological surroundings. Especially rock burst could be triggered by the instability of the fault pillar and disturbance from fault reactivation proposed by Cai et al. [26]. Therefore, the influence of two combined faults and their structure features on the mechanism of rock burst should be further systemically investigated in order to guide the monitoring and prevention of two combined faults-triggered rock bursts.

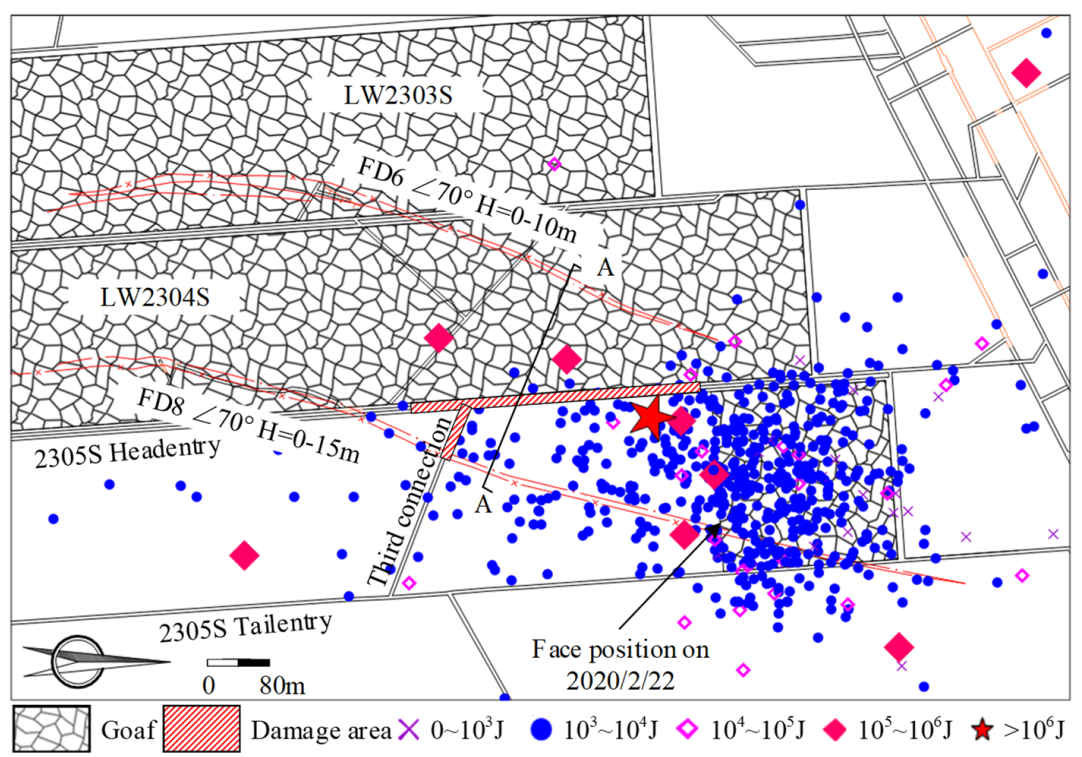

(a)

Figure 2. Cont. 


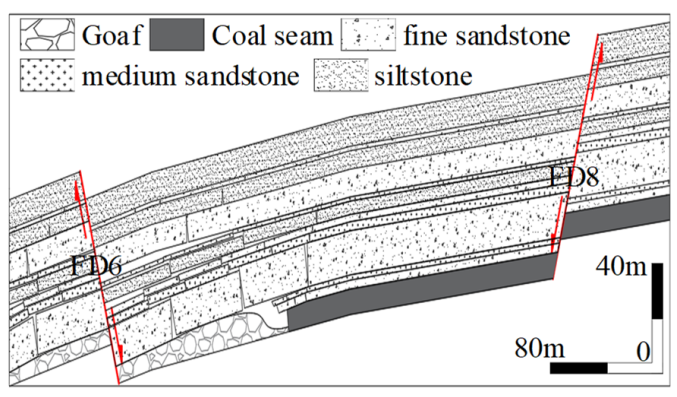

(b)

\begin{tabular}{|c|c|c|}
\hline Thickness/m & Column & Lithology \\
\hline 2.30 & & Mudstone \\
\hline 7.70 & & $\begin{array}{c}\text { Medium } \\
\text { sandstone }\end{array}$ \\
\hline 11.10 & & Siltstone \\
\hline 5.60 & & $\begin{array}{c}\text { Medium } \\
\text { sandstone }\end{array}$ \\
\hline 7.50 & & Mudstone \\
\hline 3.10 & & $\begin{array}{c}\text { Coarse } \\
\text { sandstone }\end{array}$ \\
\hline 3.00 & & Mudstone \\
\hline 37.90 & & $\begin{array}{l}\text { Sandstone } \\
\text { group }\end{array}$ \\
\hline 6.50 & & $\begin{array}{c}\text { Medium } \\
\text { sandstone }\end{array}$ \\
\hline 6.10 & & Siltstone \\
\hline 16.50 & & $\begin{array}{c}\text { Fine } \\
\text { sandstone }\end{array}$ \\
\hline 3.60 & & Siltstone \\
\hline 9.20 & & NO.3 Coal \\
\hline 4.60 & & $\begin{array}{c}\text { Fine } \\
\text { sandstone }\end{array}$ \\
\hline
\end{tabular}

(c)

Figure 2. (a) Seismic events distribution (from the time the longwall started to retreat until rock burst occurred) of LW2305S. Purple crosses represent events with energy from 0 to $10^{3} \mathrm{~J}$, blue filled circles represent events with energy from $10^{3}$ to $10^{4} \mathrm{~J}$, pink unfilled rhombuses represent events with energy from $10^{4}$ to $10^{5} \mathrm{~J}$, pink filled rhombuses represent events with energy from $10^{5}$ to $10^{6} \mathrm{~J}$, and red filled circles represent events with energy over $10^{6} \mathrm{~J}$. (b) A-A cross-section of LW2305S in (a). The red arrows represent the moving direction of the fault block. (c) Stratigraphic column of LW2305S. (It is noticed that the stratigraphic column of a longwall face is usually plotted by comprehensively considering the strata distribution around the longwall face rather than for specific sites. The same applies to similar descriptions elsewhere in this work).

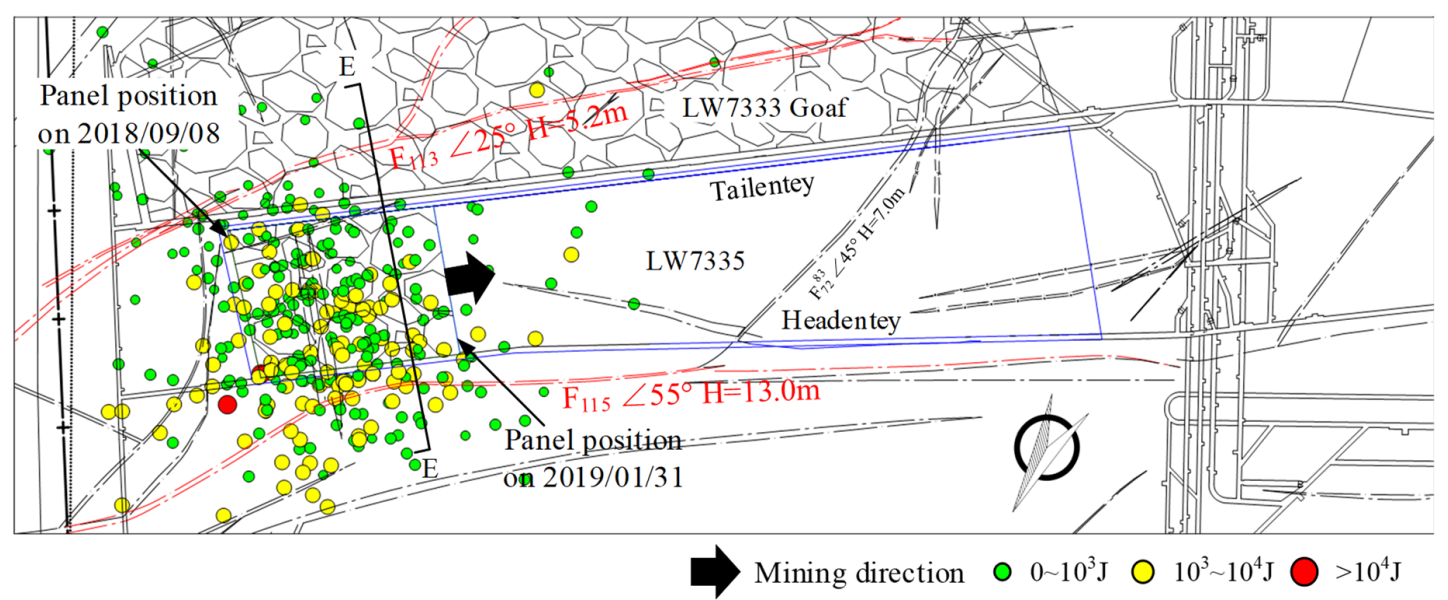

(a)

Figure 3. Cont. 


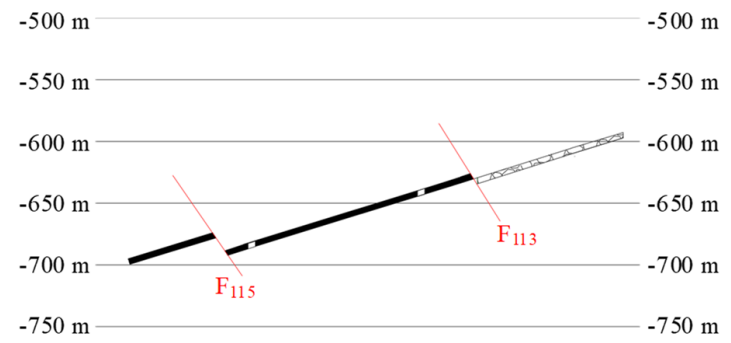

(b)

\begin{tabular}{|c|c|c|}
\hline Thickness/m & Column & Lithology \\
\hline 4.38 & & $\begin{array}{c}\text { Fine } \\
\text { sandstone }\end{array}$ \\
\hline 6.00 & & $\begin{array}{l}\text { Coarse } \\
\text { sandstone }\end{array}$ \\
\hline 2.30 & & $\begin{array}{c}\text { Fine } \\
\text { sandstone }\end{array}$ \\
\hline 3.22 & & $\begin{array}{l}\text { Sandstone } \\
\text { group }\end{array}$ \\
\hline 5.65 & & $\begin{array}{c}\text { Sandy } \\
\text { mudstone }\end{array}$ \\
\hline 1.60 & & Siltstone \\
\hline 3.68 & & $\begin{array}{c}\text { Sandy } \\
\text { mudstone }\end{array}$ \\
\hline 3.40 & & Mudstone \\
\hline 4.27 & & $\begin{array}{c}\text { Sandy } \\
\text { mudstone }\end{array}$ \\
\hline 6.07 & & $\begin{array}{l}\text { Sandstone } \\
\text { group }\end{array}$ \\
\hline 5.30 & & $\begin{array}{c}\text { Sandy } \\
\text { mudstone }\end{array}$ \\
\hline 1.05 & & Siltstone \\
\hline 5.20 & & $\begin{array}{c}\text { Fine } \\
\text { sandstone }\end{array}$ \\
\hline 6.10 & & NO.7 Coal \\
\hline 2.90 & & $\begin{array}{c}\text { Sandy } \\
\text { mudstone }\end{array}$ \\
\hline
\end{tabular}

(c)

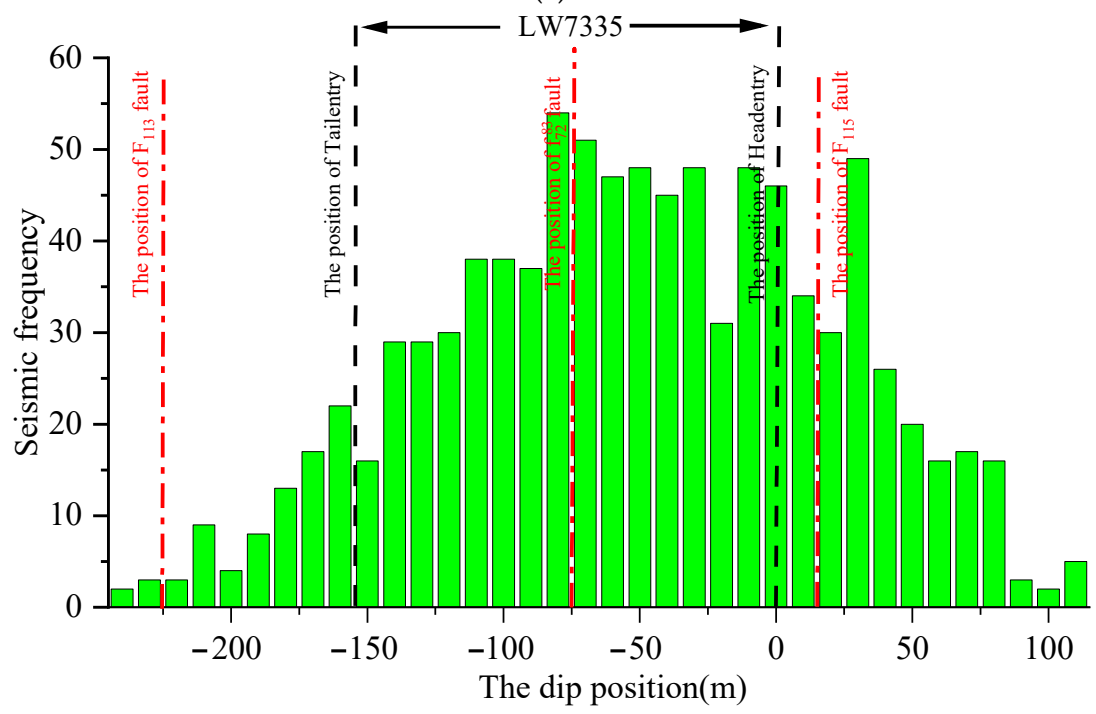

(d)

Figure 3. (a) Seismic events distribution of LW7335 between 2018/09/08 and 2019/01/31. (b) E-E cross-section of the mining coal seam in (a). (c) Stratigraphic column of LW7335. (d) The seismic events frequency distribution on the dip position of the LW7335. Green filled circles represent events with energy from 0 to $10^{3} \mathrm{~J}$, yellow filled circles represent events with energy from $10^{3}$ to $10^{4} \mathrm{~J}$, and red filled circles represent events with energy over $10^{4} \mathrm{~J}$.

\section{Influence of Two Combined Faults on Rock Bursts}

Obviously, understanding the triggering mechanism of two combined faults on rock bursts is an essential task for the improvement of mine safety. In recent years, considerable hypotheses have been expended to acquire a comprehensive understanding of rock burst 
mechanisms, such as strength [47], rigidity [48,49], burst liability [50,51], stability [52,53], and energy theory [54,55], in which stress, strain, and energy are mainly considered. To further understand the links among the three parameters and explain the rock burst mechanism, a theory that integrated the stress, energy, and displacement (i.e., stiffness) of the roof-coal-floor system was proposed by Zhang, et al. [56]. Therefore, it is critical to systematically research the triggering mechanism of two combined faults on dynamic hazards according to stress, energy, and displacement.

In this section, numerical modeling was performed to investigate the mechanism of rock burst triggered by two combined faults by simplifying to some extent. However, it is not straightforward to recognize stable and unstable rock failure (i.e., rock burst) in numerical modeling. Usually, the judgment of unstable failure in numerical modeling is performed via comparing the model response with a known model response, which is regarded as a stable failure [6]. In longwall excavation modeling, the failure mode in a model without geological structures can be considered stable (base model). On this basis, the stress, displacement, and energy responses of geological models are compared with those of non-geological models to investigate the triggering mechanism of rock burst.

\subsection{Model Setup and Material Properties}

Taking the graben fault as an example, FLAC ${ }^{3 \mathrm{D}}$ numerical modeling was performed to investigate the mechanical response caused by two combined faults. In the process, two numerical models (a base model and a graben fault model (GFM)) were established. The only difference between the base model and GFM is the presence of faults, as shown in Figure 4. Figure $4 \mathrm{a}$,c show the numerical model without faults (base model) and with faults (GFM model), respectively. To show the longwall layout more clearly, the grids hyalinized over the longwall face in Figure $4 \mathrm{a}, \mathrm{c}$ are shown in Figure $4 \mathrm{~b}, \mathrm{~d}$, respectively. The strata were simplified into floor, coal seam, immediate roof, main roof, and overburden according to the classical mining overburden movement theory [57] due to the model not being targeted to a specific engineering context.

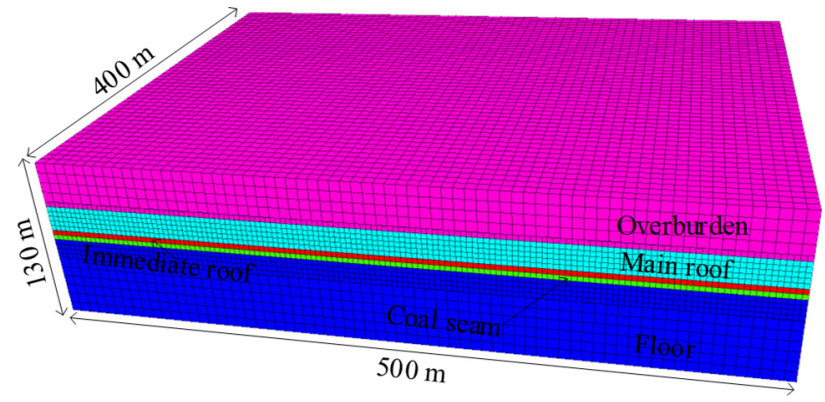

(a)

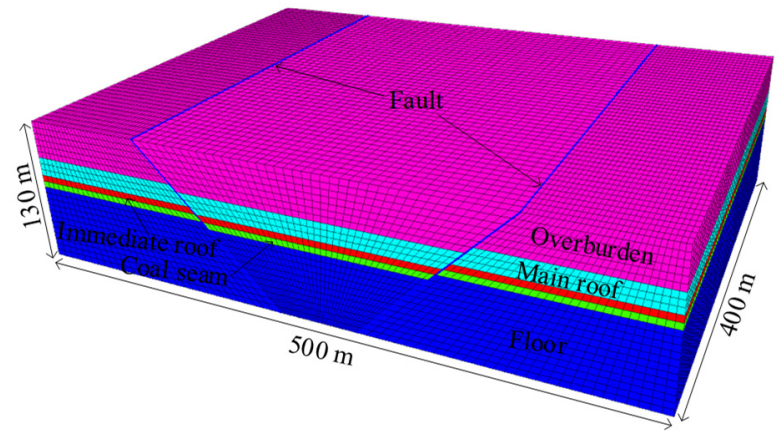

(c)

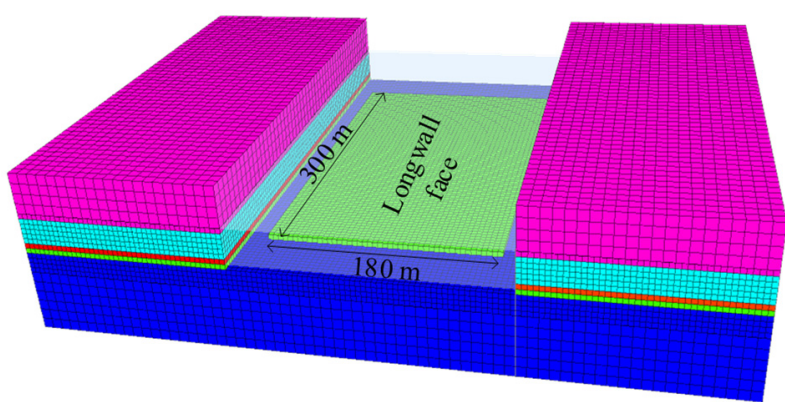

(b)

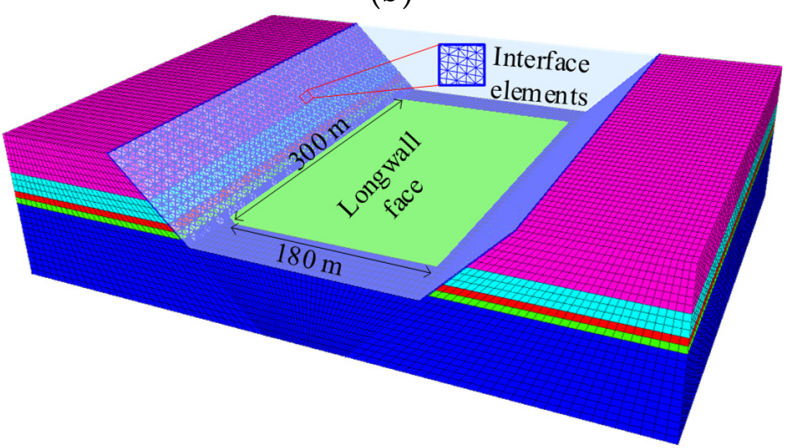

(d)

Figure 4. Numerical model of base model and graben fault model. (a) Grid model of base model. (b) Schematic of longwall face layout in base model. (c) Grid model of graben fault model. (d) Schematic of longwall face layout in graben fault model. The rock layers above the longwall face in $(\mathbf{b}, \mathbf{d})$ were made transparent in order to display the layout of the longwall. 
Figure 4 displays the numerical models with the size of $500 \mathrm{~m} \times 400 \mathrm{~m} \times 130 \mathrm{~m}$. This paper aims to obtain the mechanical response characteristics of a specific fault structure rather than to do a parametric study on the rock strata and faults. Therefore in this process, the mechanical parameters of strata and faults are obtained according to reliable literature. The origin (i.e., elastic) mechanical parameters of strata are referred from the literature [58], as seen in Table 2. In addition, to obtain the stress distributions in the model, the static displacement boundary is applied around the models. The horizontal displacements around the model and the vertical displacements at the model's bottom are fixed in the normal direction. At the top of the models, a vertical load $(\mathrm{P}=\gamma \mathrm{H}=15.0 \mathrm{MPa}$, approximately equal to the hydrostatic pressure when the coal seam buried $600 \mathrm{~m}$ ) was applied to simulate the in situ stress, while stress coefficients along the $\mathrm{x}$ - and $\mathrm{y}$-directions were set to 0.8 and 1.5 , respectively.

Table 2. Model mechanical parameters and thickness of the fault and strata. /: The interface elements do not have thickness assignments.

\begin{tabular}{|c|c|c|c|c|c|c|}
\hline Items & Thickness (m) & $\begin{array}{l}\text { Bulk Module } \\
\text { (GPa) }\end{array}$ & $\begin{array}{l}\text { Shear Module } \\
\text { (GPa) }\end{array}$ & $\begin{array}{l}\text { Cohesion } \\
(\mathrm{MPa})\end{array}$ & $\begin{array}{c}\text { Internal Friction } \\
\text { Angle }\left({ }^{\circ}\right)\end{array}$ & $\begin{array}{c}\text { Density } \\
\left(\mathrm{kg} \cdot \mathrm{m}^{-3}\right)\end{array}$ \\
\hline Overburden & 37 & 1.31 & 0.42 & 0.30 & 33 & 2500 \\
\hline Main roof & 20 & 2.30 & 1.52 & 1.7 & 38 & 2700 \\
\hline Immediate roof & 5 & 1.31 & 0.42 & 0.30 & 33 & 2500 \\
\hline Coal seam & 3 & 0.15 & 0.08 & 0.11 & 25 & 1400 \\
\hline Floor & 65 & 1.97 & 1.14 & 0.40 & 35 & 2600 \\
\hline Interface elements & / & \multicolumn{5}{|c|}{ interfacial cohesion $=2.0 \mathrm{MPa}$, interfacial friction angle $=30^{\circ}, k_{n}=k_{s} \approx 2.16 \times 10^{10} \mathrm{~Pa} / \mathrm{m}$} \\
\hline
\end{tabular}

Please note that only the normal stress and tangential stress of the fault are considered here without the effect of pore water pressure, which means that the mechanical parameters here do not consider the effect of pore water.

In addition, to simulate the excavation of the longwall face, the coal blocks in the mined area were set to the null model. Moreover, the boundary between the longwall panel and the model boundary should be $50 \mathrm{~m}$ to eliminate the boundary effect during the excavation of the longwall face. On this basis, the strain-softening model was adopted to simulate the weakening effect of rock mass after mining. The softening coefficient method suggested in the FLAC ${ }^{3 \mathrm{D}}$ manual [59] was adopted due to the absence of reliable measurements for the strata after excavation. Moreover, the fault was simulated using the interface elements (seen in Figure 4d). Since the mechanical parameters of the faults cannot really be measured, they were determined by trials in a reasonable range. Thereby, the common values of interfacial cohesion and interfacial friction angle were adopted herein as referred to Karakass [60]; the normal stiffness $\left(k_{n}\right)$ and shear stiffness $\left(k_{s}\right)$ suggested in the FLAC $^{3 \mathrm{D}}$ manual were adopted (seen in Table 2 ). Among these, $k_{n}$ and $k_{s}$ were primarily estimated to be greater than ten times the equivalent stiffness of the stiffest neighboring zone, which can be expressed as:

$$
k_{n}=k_{s} \approx 10 \cdot \max \left[\frac{K+4 G / 3}{\Delta Z_{\min }}\right]
$$

where $K$ and $G$ are the bulk and shear moduli, respectively, and $\Delta Z_{\min }$ is the smallest width of a zone in the normal direction of the interfacing surface.

\subsection{Mechanical Response of Two Combined Faults to Mining}

To investigate the mechanical response characteristic and triggering mechanism of two combined faults to mining, the difference including mining stress, displacement (i.e., stiffness), and elastic energy between graben fault model (GFM) and the base model was systematically analyzed in this section.

Figure 5 denotes the vertical stress distribution difference between the graben fault model and base model (the cross-section of $10 \mathrm{~m}$ ahead of the longwall face is selected since the abutment pressure peak area is about $10 \mathrm{~m}$ ahead of the longwall face, which 
means a higher rock burst potential over there). The vertical stress peak of the base model and GFM is $20.93 \mathrm{MPa}$ and $27.70 \mathrm{MPa}$, respectively, which also indicates that the vertical stress peak of GFM is approximately $32 \%(6.77 \mathrm{MPa})$ higher than that of the base model. Moreover, abnormal stress transitions occur near faults in GFM, as seen in Figure 5b. It can be concluded that the stress transfer on both sides of the coal pillar of the fault is obstructed due to the existence of faults, which results in stress concentration near the fault area. When the fault pillar encounters high stress and a high-stress difference state at the same time, it is easy to produce high-magnitude events, which may lead to fault activation and then trigger rock bursts [26].

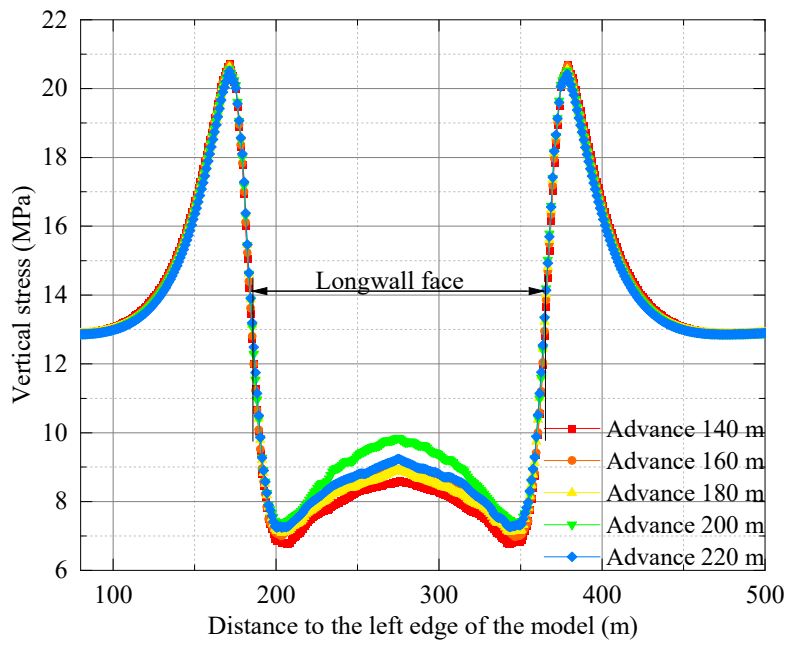

(a)

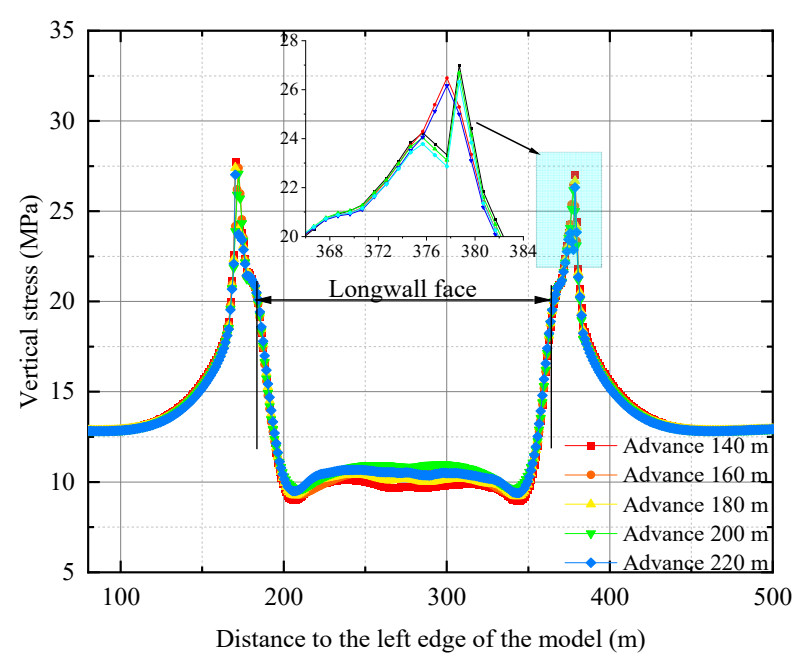

(b)

Figure 5. Vertical stress distribution curve (cross-section of $10 \mathrm{~m}$ in advance of the longwall face). (a) Base model; (b) Graben fault model.

Figure 6 shows the vertical displacement distribution difference between GFM and base model (the cross-section of $30 \mathrm{~m}$ behind the longwall face is selected, since the first weighting distance of the longwall can vary 20 to $60 \mathrm{~m}$ [61], which is accompanied by severe roof collapse and slip of goaf). The vertical displacement peak of the base model and GFM is $212 \mathrm{~mm}$ and $302 \mathrm{~mm}$, respectively, which also indicates that the vertical displacement peak of GFM is approximately $42 \%(90 \mathrm{~mm})$ higher than that of the base model. In addition, the mining-affected span and height of GFM are much larger than that of the base model (compare Figure 6a with Figure 6b). Especially as seen in Figure 6b, the roof displacement field presents a trend of migration from faults to the middle of the longwall face, which means that the existence of faults reduces the stiffness of the roof-coal-floor system.

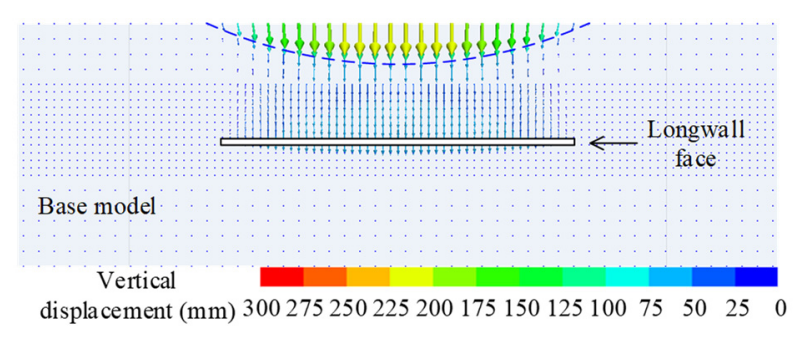

(a)

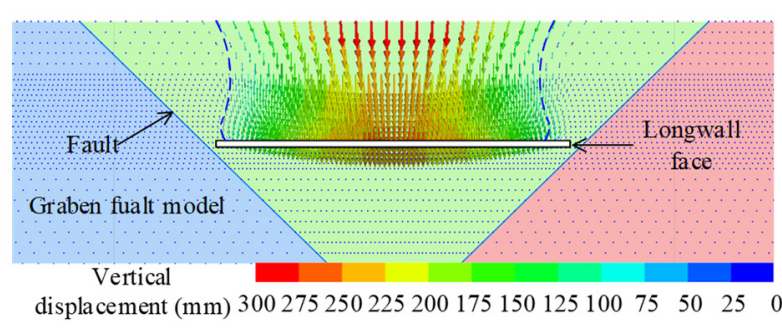

(b)

Figure 6. Vertical displacement distribution contour (cross-section of $30 \mathrm{~m}$ behind the longwall face). (a) Base model; (b) Graben fault model.

In numerical modeling, elastic energy density $W_{E}$ can be calculated as follows [58]:

$$
W_{E}=\frac{\sigma_{1}^{2}+\sigma_{2}^{2}+\sigma_{3}^{2}-2 \mu \cdot \sigma_{1} \cdot \sigma_{2}-2 \mu \cdot \sigma_{2} \cdot \sigma_{3}-2 \mu \cdot \sigma_{1} \cdot \sigma_{3}}{2 E}
$$


where $\mu$ and $E$ are the Poisson ratio and elastic modulus respectively, and $\sigma_{1}, \sigma_{2}$, and $\sigma_{3}$ are the maximum, intermediate, and minimum principal stresses of the element body, respectively.

Figure 7 depicts the elastic energy distribution difference between the GFM and base model. The elastic energy peak of the base model and GFM is $5 \times 10^{5} \mathrm{~J}$ and $7.5 \times 10^{5} \mathrm{~J}$, respectively, which also indicates that the elastic energy peak of GFM is approximately $42 \%$ $(90 \mathrm{~mm})$ higher than that of the base model. In addition, not only the energy concentration area of GFM is larger than that of the base model, but also the energy peak area of GFM is closer to the coal mass surface (Compared Figure 7a with Figure 7b). It is not hard to find that rock bursts are easily triggered in elastic energy concentration areas once the roadway and coal mass encounter instability, which may lead to catastrophic casualties and property loss.

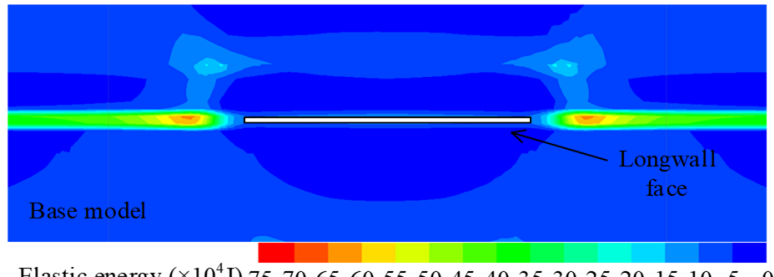

Elastic energy $\left(\times 10^{4} \mathrm{~J}\right) 757065605550454035302520151050$

(a)

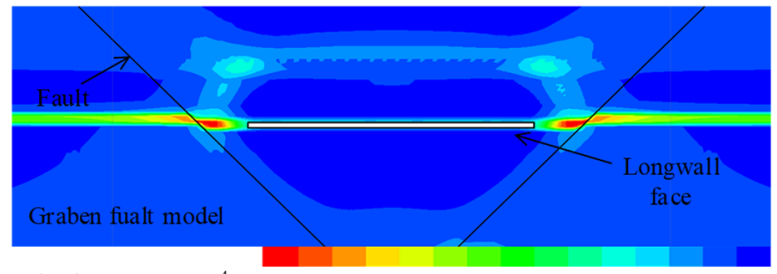

Elastic energy $\left(\times 10^{4} \mathrm{~J}\right) 757065605550454035302520151050$

(b)

Figure 7. Elastic energy distribution contour (cross-section of $30 \mathrm{~m}$ behind the longwall face). (a) Base model; (b) Graben fault model.

\subsection{Mechanism of Rock Burst Triggered by Two Combined Faults}

It follows from the above argument that the stress, displacement, and energy field of a longwall face mining near two combined faults are obviously different from those without faults. To explain the difference and mechanism of rock burst triggered by two combined faults, a theoretical model was established here.

According to the mechanical behavior of the roof, floor, and coal, the roof and floor can be assumed as linear elastomers, and coal can be assumed as a nonlinear material with strain-softening behavior [26]. When longwall mining is without faults, the stress of the coal can be expressed as $\sigma_{s}$, whose stress-strain relationship is shown on the right in Figure 8, and the corresponding roof and floor deformation behavior is shown on the left in Figure 8.

As shown in Figure 8, when the coal mass is under quasi-static loading, the strain is generated after the force is applied, and the strain generated by the cooperative deformation of roof and floor satisfies the relation:

$$
k_{1} \cdot \Delta \varepsilon_{1}=k_{2} \cdot \Delta \varepsilon_{2}
$$

where $k_{1}$ is the loading stiffness of the roof and floor, and $k_{2}$ is the unloading stiffness of the coal. The strain of the "roof-coal-floor" system can be expressed as follows:

$$
\Delta \varepsilon=\Delta \varepsilon_{1}+\Delta \varepsilon_{2}=\frac{k_{1}+k_{2}}{k_{1}} \Delta \varepsilon_{2} \Rightarrow \frac{\Delta \varepsilon_{2}}{\Delta \varepsilon}=\frac{1}{1+k_{2} / k_{1}}
$$

It can be seen that when $k_{1}+k_{2}=0, \Delta \varepsilon_{2} / \Delta \varepsilon \rightarrow \infty$. It means that the "roof-coalfloor" structure is in an extremely unstable state, and it is easy to induce rock burst when disturbed by the dynamic load. Furthermore, with the increase in deformation and energy release of the "roof-coal-floor" system, the whole system gradually tends to be stable (corresponding to point $S$ ), and the whole process corresponds to the complete process of rock burst. The whole system in this process follows the first law of thermodynamics. In other words, the elastic energy released from the roof and floor $\left(E_{1}\right)$ is equal to the energy consumed by coal deformation $\left(E_{2}\right)$ plus the elastic energy released outward $\left(E_{3}\right)$, from 
which it can be found that the elastic energy released outward $\left(E_{3}\right)$ directly determines the intensity of rock burst. The relationship between them can be expressed as:

$$
E_{3}=E_{1}-E_{2} \approx-\frac{k_{1}+k_{2}}{2 k_{1}} \cdot\left(\sigma_{b}+\sigma_{a}\right) \cdot \Delta \varepsilon_{2}=\frac{k_{1}+k_{2}}{2 k_{1} \cdot k_{2}} \cdot\left(\sigma_{b}^{2}-\sigma_{a}^{2}\right)
$$

where $\sigma_{b}$ and $\sigma_{a}$ are the stress of coal before and after rock burst (corresponding to points $S_{1}$ and $S$ in Figure 8, respectively). It can be anticipated that when $k_{1}+k_{2}<0, E_{3}>0$, which is consistent with the conclusion of strength and stiffness theory [62]. When the "roof-coal-floor" is disturbed by dynamic load (roof breakage, fault slip, etc.), it can be considered that external energy $E_{4}$ is applied to it. At this time, the stress state of coal rises from point $S_{1}$ to point $S_{2}$, which is closer to the peak strength of coal. More energy is released when instability occurs, and the strength is greater when a rock burst occurs. In addition, when the stress of coal is located at point $S_{2}^{\prime}$, although it does not exceed the peak strength at this time, due to the strain-softening behavior of the coal mass or the dynamic load disturbance, the deformation increases with time and enters the deformation stage after the peak strength (reaching point $S_{1}$ or $S_{2}$ ), which will induce rock burst [63].

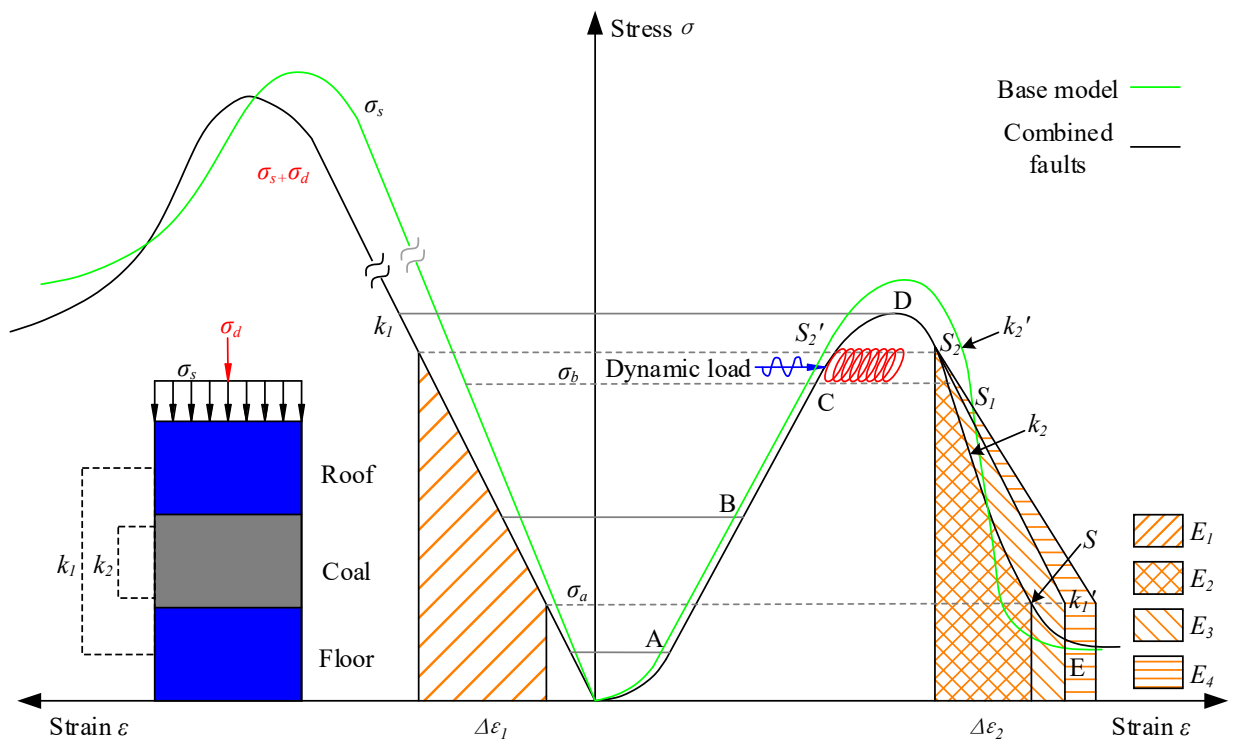

Figure 8. Schematic diagram of rock burst mining near the combined faults.

It can be seen from Section 3.2 that the stress of coal pillars on both sides of the longwall significantly increases due to the presence of faults, which results in a significant increase in the stress level of the "roof-coal-floor" system (as shown by the green curve in Figure 8). In addition, the existence of combined faults reduces the overall stiffness of "roof-coal-floor" (seen in Section 3.2), which means that the stiffness of roof and floor and the unloading stiffness of coal increase significantly (roof and floor stiffness rise from point $k_{1}$ to point $k_{1}^{\prime}$, and coal unloading stiffness rises from point $k_{2}$ to point $k_{2}^{\prime}$ ). According to Equation (5), when the loading stiffness of the roof and floor and the unloading stiffness of coal increase simultaneously, the elastic energy released during the instability of "roof-coal-floor" will greatly increase (it is fully proved by the energy field distribution in Section 3.2), which could lead to the rock burst and more release of elastic energy.

Therefore, the occurrence of rock burst triggered by two combined faults is the result of the joint action of the "roof-coal-floor" system. The special roof structure near the two combined faults mining prevents longwall face lateral abutment pressure from transferring to deep rock mass, which leads to stress concentration near the fault areas. Otherwise, a special roof structure causing the lower system stiffness of mining gives rise to the easier gathering of elastic energy in coal pillars, which is higher than those without faults and means higher rock burst risk. 


\section{Effects of Two Combined Faults on Rock Burst Potential}

It follows from the above statement that the existence of two combined faults leads to a significant increase in the rock burst potential of the longwall face. Thereby, it is necessary to carry out a systematic investigation, including the influence of different parameters of two different combined faults on rock burst potential.

\subsection{Definition of Rock Burst Potential Assessment Indexes}

Many case studies have proven that the occurrence mechanism of rock burst should be accounted for the static load, dynamic load, and superposition effect of them [64-69]. Moreover, when longwall face mining near the faults, fault pillar instability and fault activation are two main causes of rock burst $[25,26]$. Therefore, two rock burst potential assessment indexes were proposed in this section considering aforesaid static and dynamic load to investigate the response characteristics of different parameters to mining near two combined faults.

There are three types of principal stress transformation of coal and rock mass under load (as seen in Figure 9): (1) the Mohr circle remains the same size and shifts its position, i.e., $\left|\sigma_{1}-\sigma_{3}\right|$ remains constant; (2) the Mohr circle changes in size while its position remains constant, i.e., $\sigma_{1}$ and $\sigma_{3}$ get bigger or smaller simultaneously and $\left|\sigma_{1}-\sigma_{3}\right|$ makes changes; (3) the Mohr circle changes in size and position, i.e., $\left|\sigma_{1}-\sigma_{3}\right|$ makes changes. In this process, according to the Mohr-Coulomb strength criterion of single discontinuity [70], rock mass failure occurs when the Mohr circle intersects or tangles the strength curve, as shown in Figure 9. It is further deduced that the smaller the distance between the Mohr circle and strength curve is, the worse the stability of the rock mass is and the more rock burst risk.

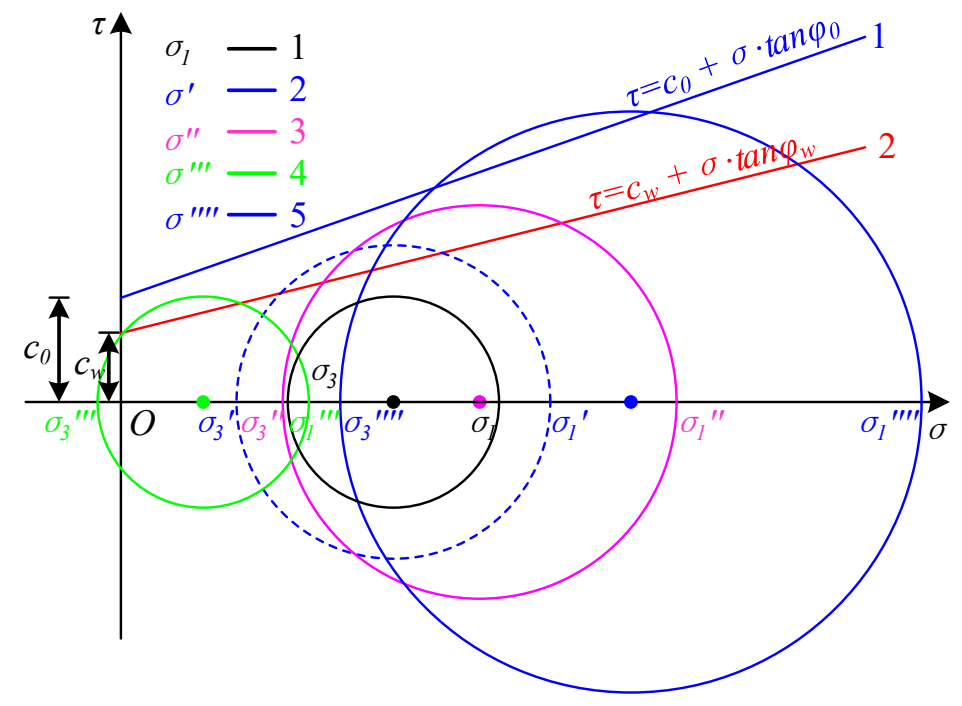

Figure 9. Normal stress transformation form based on Coulomb failure criterion where $\sigma_{1}$ and $\sigma_{3}$ are the initial maximum and minimum principal stress of rock mass respectively. $\sigma_{1}^{\prime}$ and $\sigma_{3}^{\prime}$ are respectively the maximum and minimum principal stresses of rock mass after transformation.

On this basis, PANG, et al. [71] considering the transformation of three principal stresses proposed the criterion of instability of complete rock mass, which can be expressed as:

$$
k_{3 d}=\left|\frac{\sigma_{1}^{\prime}-\sigma_{3}^{\prime}}{\sigma_{1}-\sigma_{3}}\right| \frac{2 c \cdot \cot \varphi+\sigma_{1}+\sigma_{3}}{2 c \cdot \cot \varphi+\sigma_{1}^{\prime}+\sigma_{3}^{\prime}}
$$

where $c$ and $\varphi$ represent the cohesion and internal friction angle of coal and rock mass, respectively. It can be inferred that the larger the $k_{3 d}$ is, the closer to or beyond the strength limit of coal and rock mass, the stronger the disturbance state of surrounding rock, leading to the higher the rock burst risk. 
In addition, it can be deduced that in the process of normal stress transformation near the fault, when the principal stress is in the nearly same direction as the fault dip, the fault is easier to be activated (which means that the stiffness of the "roof-coal-floor" system is lower). On this basis, a disturbance instability index (DII) was proposed here as an improvement on $k_{3 d}$ to assess the rock burst potential caused by static load transformation, which can be expressed as:

$$
D I I=k_{3 d} \cdot f_{\text {sin }}
$$

where $f_{\text {sin }}$ is the sine value of the direction of maximum principal stress at a certain point in the surrounding rock and the normal vector of the fault plane.

Furthermore, in order to evaluate risk caused by fault activation, maximum fault slip rate $\left(F_{v}\right)$ is proposed to assess the rock burst potential caused by dynamic load (the faster fault slip velocity can lead to greater dynamic load and more rock burst potential [32,72]. Especially in FLAC ${ }^{3 \mathrm{D}}$, the $F_{v}$ of the fault plane can be recorded directly using embedded FISH language.

\subsection{Influence of Different Parameters of Two Combined Faults on Rock Burst Potential}

When mining longwall faces near the faults, several parameters, including fault throw, fault dip, mining height, and fault pillar width are the essential factors influencing the stability of longwall faces [26]. Thereby, in this section, a series of numerical modeling was performed to systematically research the influence of different parameters of two combined faults on rock burst potential. In this process, the control variable method was adopted. For example, when studying the effect of fault drop changes on the longwall face, five numerical models were set up, in which model parameters and the excavation mode of the longwall face were consistent with the model (as shown in Figure 4c,d), except that the fault throw was successively changed to $4 \mathrm{~m}, 6 \mathrm{~m}, 8 \mathrm{~m}, 10 \mathrm{~m}$, and $12 \mathrm{~m}$.

Figure 10a shows the distribution of DII and $F_{v}$ with different fall throws during longwall retreat. It can be seen that DII fluctuates as the fault throw increases, and DII reaches the peak when the fault throw is between 6 and $8 \mathrm{~m}$. In addition, $F_{v}$ firstly increases with the increase in fault throw and then gradually stabilizes in a relatively stable range, which means that the increase in fault throw results in a limited disturbance of dynamic load. Comprehensively considering the response of DII and $F_{v}$ to the increase in fault throw, the longwall has a relatively high rock burst potential when the fault throw varies from 6 to $8 \mathrm{~m}$.

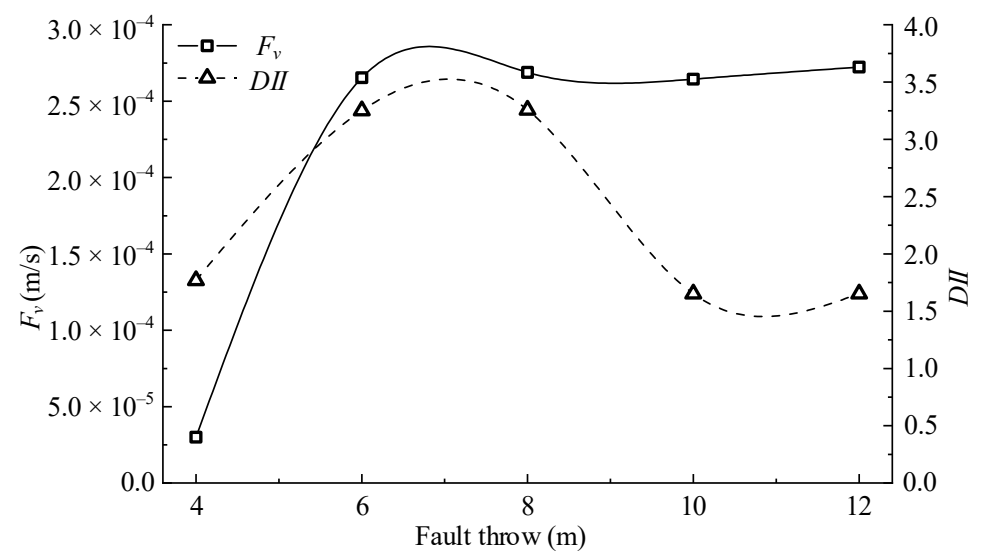

(a)

Figure 10. Cont. 


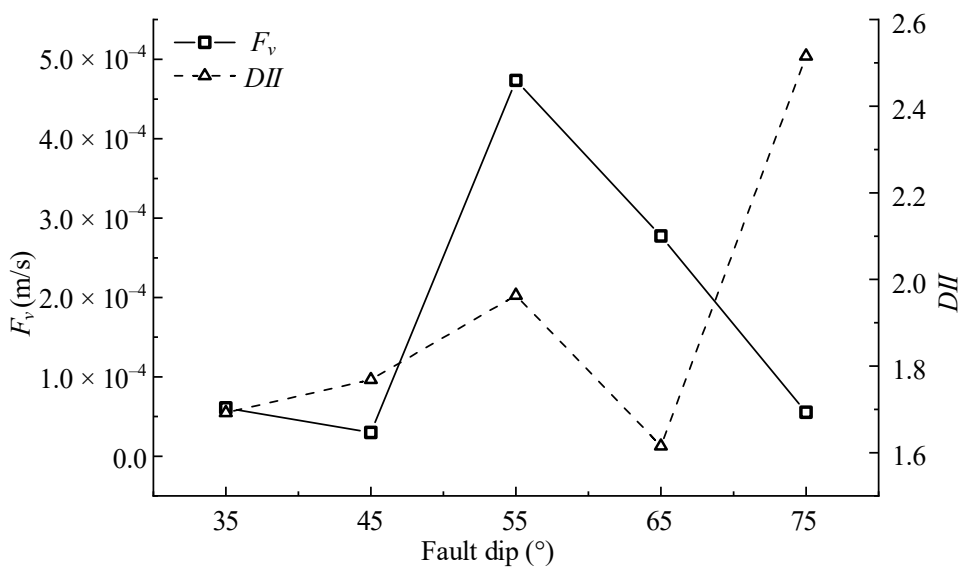

(b)

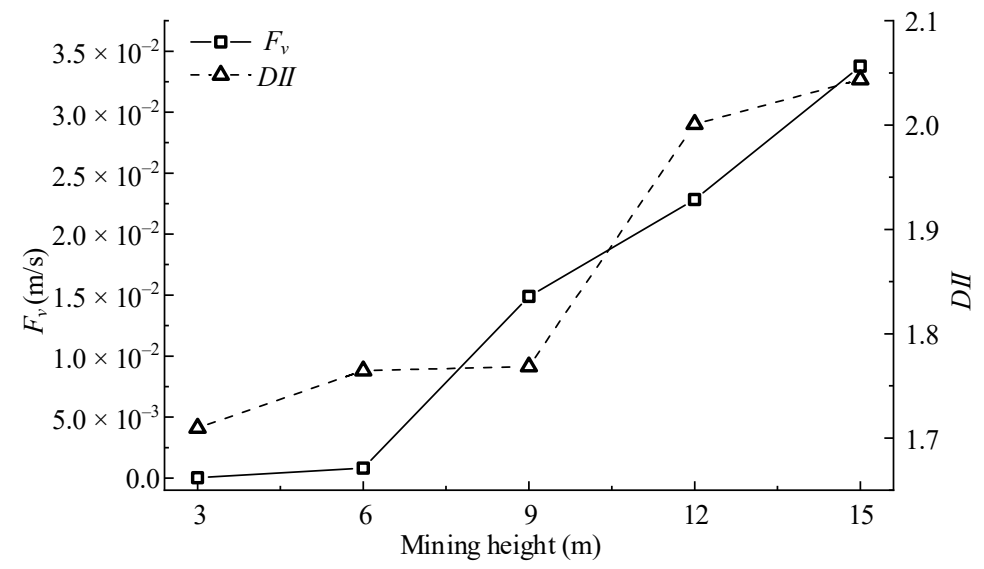

(c)

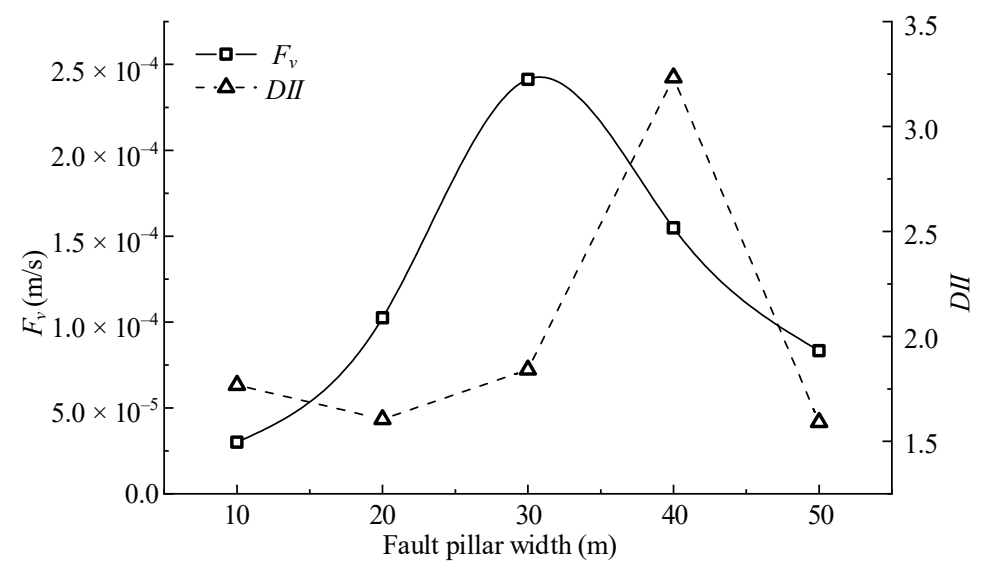

(d)

Figure 10. Change of rock burst potential under the influence of different factors based on proposed rock burst potential assessment indexes. (a) Influence of different fault throw on rock burst potential. (b) Influence of different fault dip on rock burst potential. (c) Influence of different mining height on rock burst potential. (d) Influence of different fault pillar width on rock burst potential.

Figure $10 \mathrm{~b}$ depicts the distribution of DII and $F_{v}$ with different fall dips during longwall retreat. It is noted that DII fluctuates as the fault dip increases when fault dip is less than $65^{\circ}$, and DII increases rapidly when fault dip is larger than $65^{\circ} . F_{v}$ reaches the peak when the fault dip is equal to $55^{\circ}$. Moreover, when the fault dip reaches $65^{\circ}$, the rapid rise of DII means that the increase in fault dip will lead to a sharp increase in the stress concentration of the fault pillar. 
Figure 10c displays the distribution of DII and $F_{v}$ with different mining heights during longwall retreat. It is found that both DII and $F_{v}$ show an obvious upward trend with the increase in mining height. It means that the increase in mining height will lead to the increase in the static and dynamic load of the longwall face, further resulting in higher rock burst risk, which is unfavorable to risk management. In addition, DII and $F_{v}$ show a more obvious upward trend when the mining height is larger than $6 \mathrm{~m}$. Therefore, the mining height should be reduced to below $6 \mathrm{~m}$ as far as possible in order to effectively reduce the rock risk potential.

Figure $10 \mathrm{~d}$ shows the distribution of DII and $F_{v}$ with different fault pillar widths during longwall retreat. Both $D I I$ and $F_{v}$ increase first and then decrease with the increase in pillar width, and DII and $F_{v}$ reach the peak when the pillar width is equal to $30 \mathrm{~m}$ and $40 \mathrm{~m}$, respectively. Additionally, both $D I I$ and $F_{v}$ are at extremely high levels when the fault pillar width is between 20 and $50 \mathrm{~m}$. Consequently, the fault pillar width should be more than $50 \mathrm{~m}$ to effectively reduce the burst risk.

According to the analysis of the influence of different parameters of two combined faults on rock burst potential, it can be concluded that the change of fault throw, fault dip, mining height, and fault pillar width will make the static and dynamic load change significantly. Furthermore, none of them are linearly related to the level of static or dynamic load. It is observed that the longwall face has the highest rock burst risk when the fault throw is between 6 and $8 \mathrm{~m}$, the fault dip is larger than $65^{\circ}$, the mining height is greater than $6 \mathrm{~m}$, and the coal pillar width is less than $50 \mathrm{~m}$.

\subsection{Identification of Main Control Factors of Rock Burst}

It has been widely acknowledged that the monitoring, warning, and prevention of rock burst must be targeted [73]. As for mining near the combined faults, the main control factors should be identified for further targeted prevention and control measures. The influenced parameters that triggered rock burst risk such as fault throw, dip, mining height, and fault pillar width have been investigated in Section 4.2. However, mining height can be adjusted flexibly when it leads to a high burst risk. Thereby, in this section, the fault throw, dip, and fault pillar width were tested to identify the main control factors of rock burst in different two combined faults models. Moreover, the DII and $I_{V}$ were used to evaluate the static and dynamic burst risk, respectively.

As for the fault throw, dip, and fault pillar width, if each factor contains four parameters and the experiment is conducted using the control variable method, there will be a total of 64 schemes, which will result in a huge amount of computation and data processing and is unfavorable for data analysis. To solve the problem, the orthogonal experiment method [74] is widely adopted to study this approach of multiple factors and levels (i.e., parameters) problems. Due to three factors being considered here, an orthogonal table with four factors and three levels $\left(3^{4}\right)$ is adopted, as shown in Table 3 . In addition, the difference between the different parameters of each factor should be as large as possible for the more obvious results difference and facilitating the analysis (seen in Table 3). Table 4 shows the orthogonal test schemes of four factors and three levels $\left(3^{4}\right)$. On this basis, several numerical models (as shown in Figure 11) corresponding to the six aforesaid two combined faults types were set up to identify the main control factors of rock burst, in which the model setups and material properties are the same as those mentioned in Section 3.1.

Table 3. Orthogonal test factor levels and model parameters.

\begin{tabular}{llll}
\hline \multirow{2}{*}{ Level } & A & B & C \\
& Throw $(\mathbf{m})$ & Dip $\left({ }^{\circ}\right)$ & Pillar Width (m) \\
\hline 1 & 4 & 45 & 10 \\
2 & 8 & 60 & 40 \\
3 & 12 & 75 & 70 \\
\hline
\end{tabular}


Table 4. Orthogonal test schemes of four factors and three levels $\left(3^{4}\right)$.

\begin{tabular}{lllll}
\hline \multirow{2}{*}{ Level (Scheme) } & A & B & C & D \\
& Throw $(\mathbf{m})$ & Dip $\left({ }^{\circ}\right)$ & Pillar Width $(\mathbf{m})$ & / \\
\hline 1 & 4 & 45 & 10 & $/$ \\
2 & 4 & 60 & 40 & $/$ \\
3 & 4 & 75 & 70 & $/$ \\
4 & 8 & 45 & 70 & $/$ \\
5 & 8 & 60 & 10 & $/$ \\
6 & 8 & 75 & 40 & $/$ \\
7 & 12 & 45 & 40 & $/$ \\
8 & 12 & 60 & 70 & $/$ \\
9 & 12 & 75 & 10 & \\
\hline
\end{tabular}
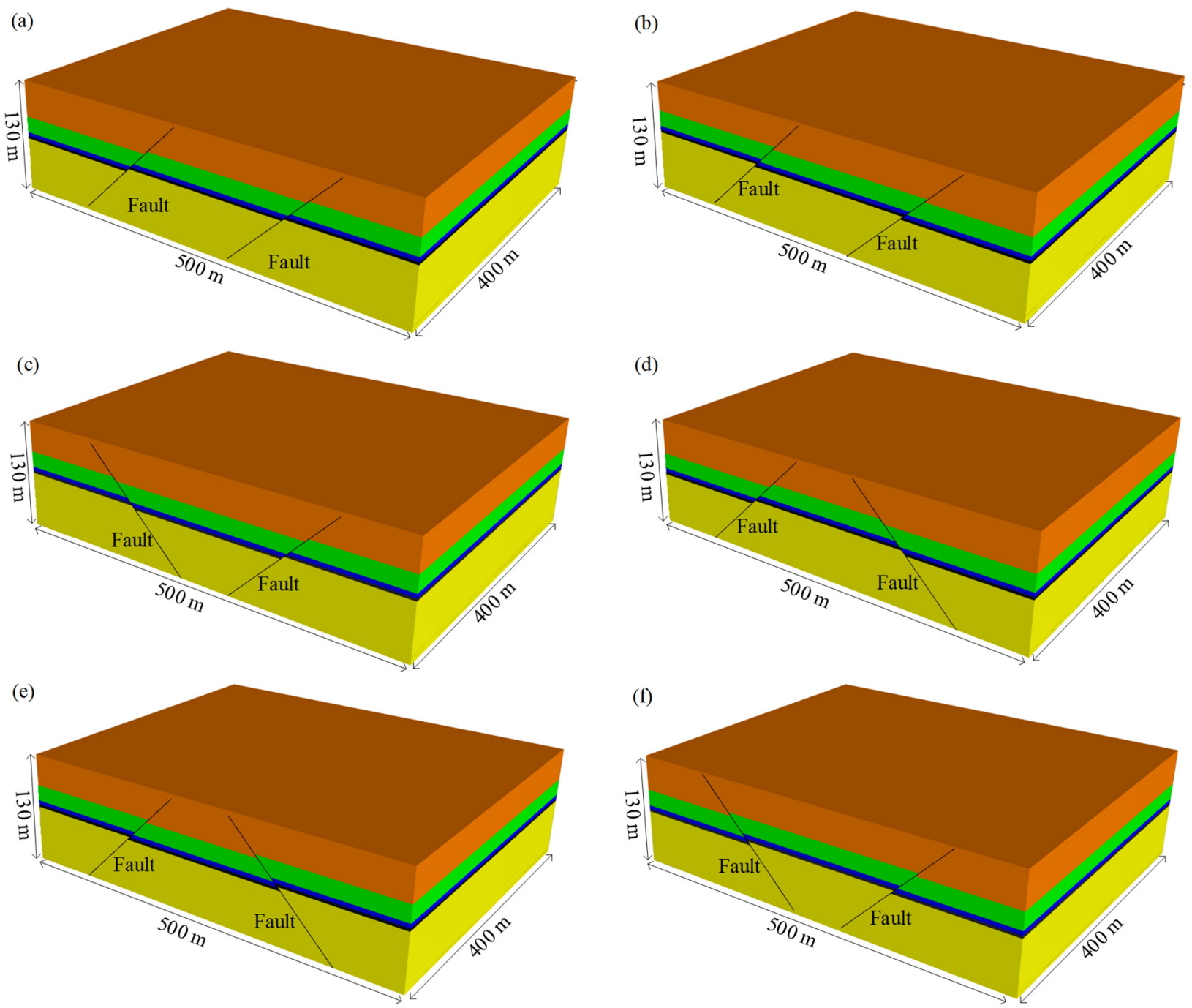

Figure 11. The numerical models of the different two combined faults. (a) Stair-stepping fault model. (b) Imbricate fault model. (c) Graben fault model. (d) Horst fault model. (e) Back thrust fault model. (f) Ramp fault model. The $\square$ blocks represent overburdens; the blocks represent main roofs; the blocks represent immediate roofs; the $\square$ blocks represent coal seams; and the blocks represent floors.

Figure 12a shows the DII distribution of different orthogonal experiment results. For six different combined faults, the distribution of DII is relatively high and close to each other except for some special cases, which indicates that the excavation of the longwall face in the middle of the faults leads to lateral abutment pressure, and the existence of 
faults on both sides leads to stress concentration near the faults. Furthermore, the similar DII distribution of different combined faults indicates that the correlation between stress concentration and faults type is weak. Additionally, for a special two combined faults type, the difference of DII among different experimental schemes was also small except for some cases, which means that the longwall face will always be affected by high static stress when mining near the combined faults and targeted prevention and control measures should be implemented.

Figure $12 \mathrm{~b}$ shows the $I_{V}$ distribution of different orthogonal experiment results. It can be seen that the $I_{V}$ distribution varies among different combined faults, in which all experimental schemes have relatively low $I_{V}$ values in back thrust fault and graben fault models and the rest of the models have relatively high $I_{V}$ values. Furthermore, it is noticed that the maximum $I_{V}$ values all appear in scheme 9 of the other four combined faults models, in which the fault throw and dip are the maximum and the pillar width is the minimum in all experimental schemes (seen in Table 4). The larger the fault throw and dip, the smaller the pillar width when mining near the combined faults, which will lead to higher dynamic risk.

In orthogonal experimental analysis, the sample range $(R)$ is usually used to determine the order of influence factors, which can be expressed as:

$$
R=\max \left\{K_{1}, K_{2}, \cdots, K_{i}\right\}-\min \left\{K_{1}, K_{2}, \cdots, K_{3}\right\}
$$

where $i$ represents the number of influencing factors, and $K_{i}$ represents the sum of the corresponding test results when the parameters of any column of orthogonal test table are the same (as shown in Table 4).

Figure 12c denotes the sample range of DII relating to different orthogonal experimental schemes. It can be seen that the fault pillar width is the primary control factor in the stair-stepping fault and back thrust fault model. Fault throw is the main control factor in the graben fault model, and there are few differences between the three factors in the imbricate fault model, horst fault model, and ramp fault model. It can be concluded that the main control factors are variable when mining near the different combined faults. It warns us that the exploration of fault occurrence must be strengthened, especially for the actual mining process, as faults are variable.

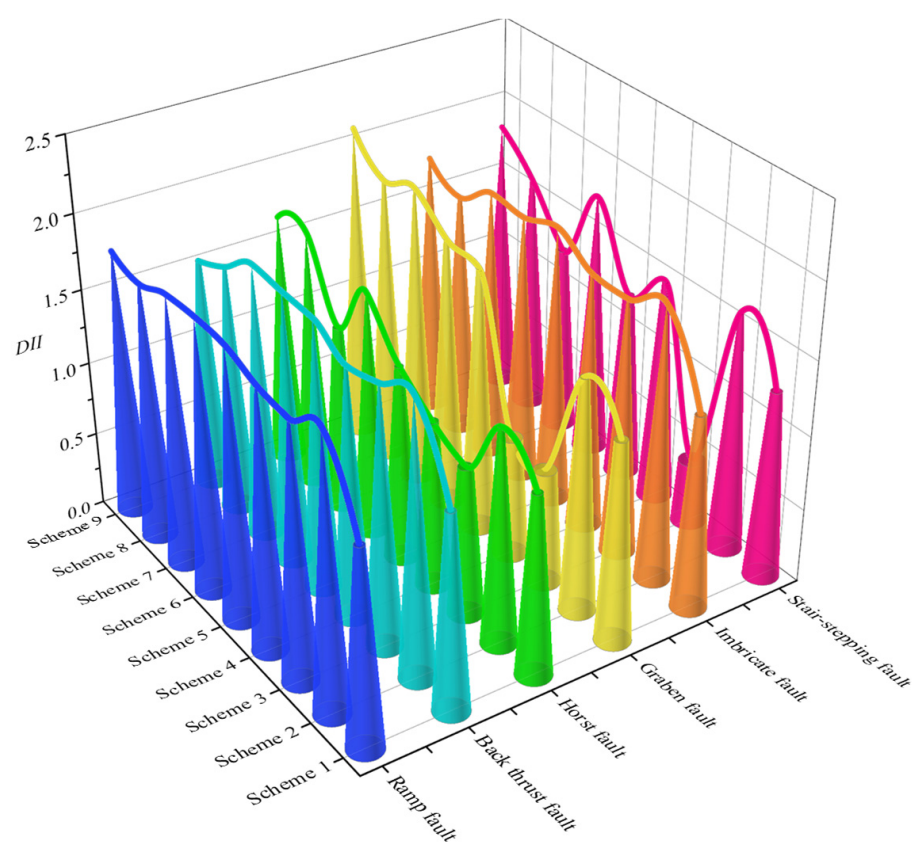

(a)

Figure 12. Cont. 


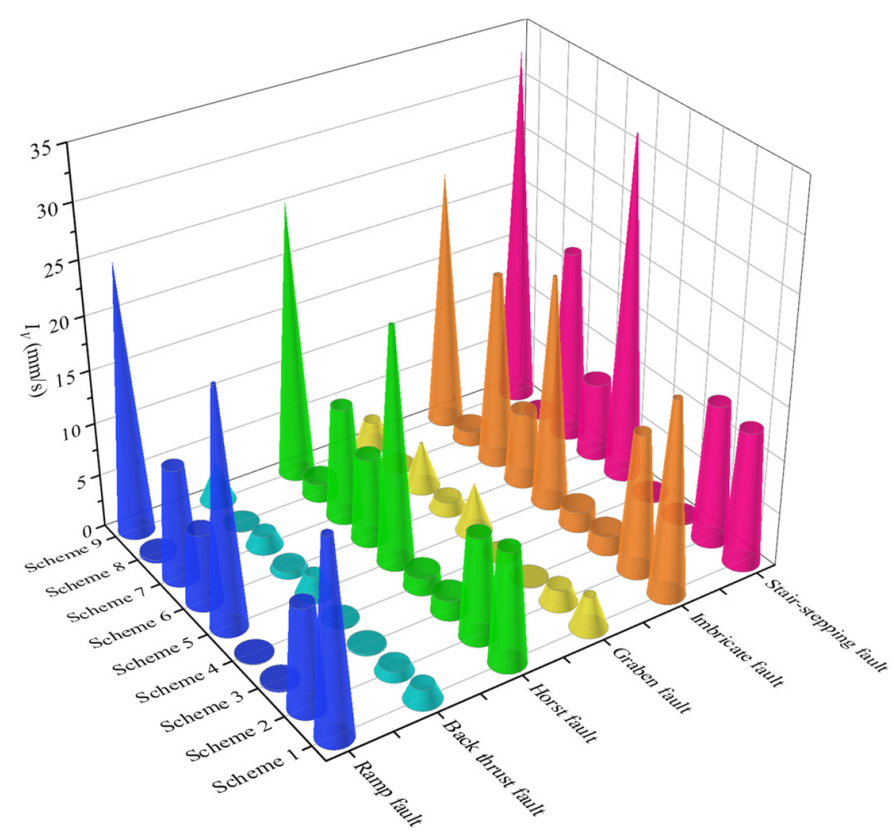

(b)

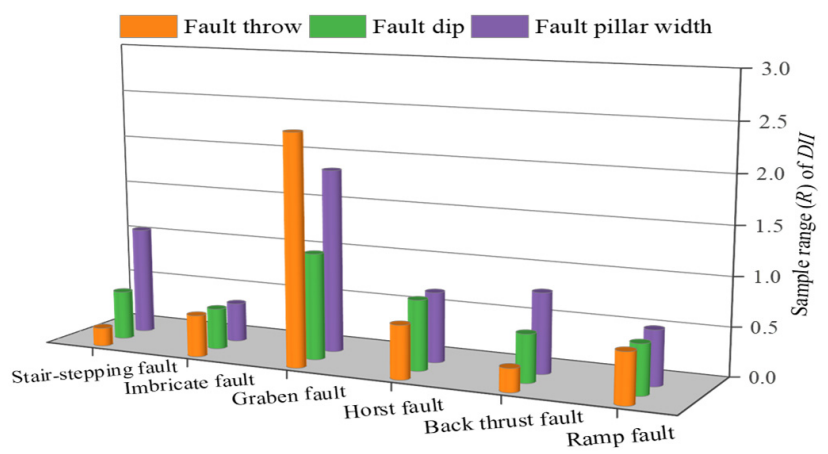

(c)

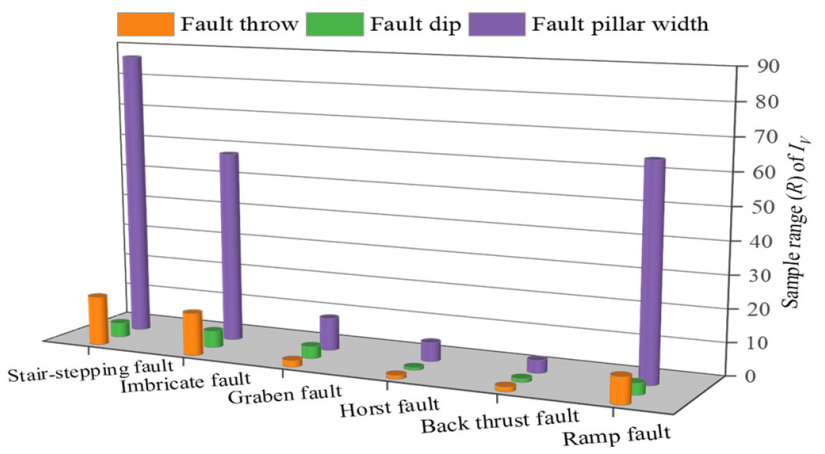

(d)

Figure 12. Orthogonal experimental results. (a,b) represent $D I I$ and $I_{V}$ distribution of different orthogonal experimental schemes, respectively. (c,d) represent the sample range of DII and $I_{V}$ correspond to different orthogonal experimental schemes respectively. 
Figure $12 \mathrm{~d}$ presents the sample range of $I_{V}$ corresponding to different orthogonal experimental schemes. It can be seen that fault pillar width is the primary control factor in all fault models. Especially for the stair-stepping fault, imbricate fault, and ramp fault model, the sample range of $I_{V}$ of the fault pillar width is much greater than that of the fault throw and dip, which means inappropriate fault pillars should be avoided primarily to avoid triggering significant activation of the fault.

It follows from the above statement that the presence of two combined faults will result in high static load stress, and specific combined fault types will produce higher dynamic load stress (e.g., stair-stepping, imbricate, horst, and ramp fault model) during longwall retreat. As for different combined faults, the main control factors leading to the rise of static load stress of longwall are different, in which fault pillar width is the most significant factor. In addition, the fault pillar width is the primary control factor in all fault models, leading to dynamic proneness.

\section{Conclusions}

In underground burst-prone coal mines, the combined faults have become the critical factors that induced rock burst potential. The types of two combined faults were first classified in this work. On this basis, the rock burst mechanism and control factors were systematically investigated. The following conclusions can be drawn:

(1) According to types of two embedded faults, six types of two combined faults can be summarized, including stair-stepping fault, imbricate fault, graben fault, horst fault, back thrust fault, and ramp fault.

(2) The particular roof structure near the two combined faults mining preventing longwall face lateral abutment pressure from transferring to deep rock mass leads to stress concentration near the fault areas. Otherwise, a special roof structure causing the lower system stiffness of mining gives rise to the easier gathering of elastic energy in coal pillars, which makes it easier to trigger a rock burst.

(3) The analysis of the influence of different parameters of graben faults on rock burst potential shows that none of them are linearly related to the level of static or dynamic load. It is noticed that the longwall face has the highest rock burst risk when the fault throw is between 6 and $8 \mathrm{~m}$, the fault dip is larger than $65^{\circ}$, the mining height is greater than $6 \mathrm{~m}$, and the coal pillar width is less than $50 \mathrm{~m}$.

(4) This approach of combined faults (i.e., stair-stepping, imbricate, horst, and ramp fault model) will produce higher dynamic load stress during longwall retreat. The main control factor for different two combined faults leading to the rise of static load stress and dynamic proneness is different in which fault pillar width is the most significant factor.

Author Contributions: Conceptualization, A.C. and Y.L.; methodology, Y.L.; software, Y.L.; validation, S.J., Q.H. and Y.P.; formal analysis, Y.L. and S.J.; investigation, A.C. and Y.L.; resources, A.C. and Y.L.; data curation, X.Y.; writing—original draft preparation, A.C., Y.L., X.B. and X.Y.; writing—review and editing, A.C. and Y.L.; visualization, A.C. and Y.L.; supervision, Y.L.; project administration, A.C.; funding acquisition, A.C. and Y.L. All authors have read and agreed to the published version of the manuscript.

Funding: This research was carried out by the funded projects: National Natural Science Foundation of China (51734009), Shandong Provincial Department of Science and Technology (2019SDZY02) and Graduate Research and Practice Innovation Program of Jiangsu Province (KYCX21_2350).

Data Availability Statement: Not applicable.

Conflicts of Interest: The authors declared that they have no conflict of interest to this work. 


\section{References}

1. Akdag, S.; Karakus, M.; Nguyen, G.D.; Taheri, A.; Bruning, T. Evaluation of the propensity of strain burst in brittle granite based on post-peak energy analysis. Undergr. Space 2021, 6, 1-11. [CrossRef]

2. Cao, A.; Dou, L.; Cai, W.; Gong, S.; Liu, S.; Jing, G. Case study of seismic hazard assessment in underground coal mining using passive tomography. Int. J. Rock Mech. Min. Sci. 2015, 78, 1-9. [CrossRef]

3. Faradonbeh, R.S.; Taheri, A.; Karakus, M. The propensity of the over-stressed rock masses to different failure mechanisms based on a hybrid probabilistic approach. Tunn. Undergr. space Technol. 2022, 119, 104214. [CrossRef]

4. Jiang, L.; Wu, Q.; Wu, Q.; Wang, P.; Xue, Y.; Kong, P.; Gong, B. Fracture failure analysis of hard and thick key layer and its dynamic response characteristics. Eng. Fail. Anal. 2019, 98, 118-130. [CrossRef]

5. Khan, M.; He, X.; Farid, A.; Song, D.; Li, Z.; Tian, X.; Ni, M. A novel geophysical method for fractures mapping and risk zones identification in a coalmine, Northeast, China. Energy Rep. 2021, 7, 3785-3804. [CrossRef]

6. Manouchehrian, A.; Cai, M. Numerical modeling of rockburst near fault zones in deep tunnels. Tunn. Undergr. Space Technol. 2018, 80, 164-180. [CrossRef]

7. Vardar, O.; Zhang, C.; Canbulat, I.; Hebblewhite, B. Numerical modelling of strength and energy release characteristics of pillar-scale coal mass. J. Rock Mech. Geotech. Eng. 2019, 11, 935-943. [CrossRef]

8. Wang, C.; Cao, A.; Zhu, G.; Jing, G.; Li, J.; Chen, T. Mechanism of rock burst induced by fault slip in an island coal panel and hazard assessment using seismic tomography: A case study from Xuzhuang colliery, Xuzhou, China. Geosci. J. 2017, 21, 469-481. [CrossRef]

9. Wang, H.; Shi, R.; Lu, C.; Jiang, Y.; Deng, D.; Zhang, D. Investigation of sudden faults instability induced by coal mining. Saf. Sci. 2019, 115, 256-264. [CrossRef]

10. Dou, L.; He, X. Theory and Technology of Rock Burst Prevention; China University of Mining and Technology Press: Xuzhou, China, 2001.

11. Keneti, A.; Sainsbury, B.-A.; Dargaville, R. Consideration of Strain-Bursting Phenomena Associated with Large-Scale Discontinuities: A Numerical Study. Pure Appl. Geophys. 2021, 178, 3581-3600. [CrossRef]

12. Sainoki, A.; Schwartzkopff, A.K.; Jiang, L.; Mitri, H.S. Numerical Modeling of Complex Stress State in a Fault Damage Zone and Its Implication on Near-Fault Seismic Activity. J. Geophys. Res.: Solid Earth 2021, 126, e2021JB021784. [CrossRef]

13. Wang, P.; Jiang, L.; Jiang, J.; Zheng, P.; Li, W. Strata Behaviors and Rock Burst-Inducing Mechanism under the Coupling Effect of a Hard, Thick Stratum and a Normal Fault. Int. J. Geomech. 2018, 18, 04017135. [CrossRef]

14. Wang, P.; Jiang, L.-s.; Zheng, P.-q.; Qin, G.-p.; Zhang, C. Inducing mode analysis of rock burst in fault-affected zone with a hard-thick stratum occurrence. Environ. Earth Sci. 2019, 78, 467. [CrossRef]

15. Pang, Y. Study on Rock Burst Initiation and Failure Propagation; Tsinghua University: Beijing, China, 1999.

16. Feng, J.; Wang, E.; Ding, H.; Huang, Q.; Chen, X. Deterministic seismic hazard assessment of coal fractures in underground coal mine: A case study. Soil Dyn. Earthq. Eng. 2020, 129, 105921. [CrossRef]

17. Keneti, A.; Sainsbury, B.-A. Review of published rockburst events and their contributing factors. Eng. Geol. 2018, 246, 361-373. [CrossRef]

18. Ortlepp, W.D.; Armstrong, R.; Ryder, J.A.; O'Connor, D. Fundamental Study of Micro-Fracturing on the Slip Surface of MineInduced Dynamic Brittle Shear Zones. In Proceedings of the 6th International Symposium on Rockburst and Seismicity in Mines, Perth, Australia, 9-11 March 2005.

19. Hofmann, G.F.; Scheepers, L.J. Simulating fault slip areas of mining induced seismic tremors using static boundary element numerical modelling. Min. Technol. 2011, 120, 53-64. [CrossRef]

20. Sainoki, A.; Mitri, H.S. Back analysis of fault-slip in burst prone environment. J. Appl. Geophys. 2016, 134, 159-171. [CrossRef]

21. Alber, M.; Fritschen, R. Rock mechanical analysis of a Ml= 4.0 seismic event induced by mining in the Saar District, Germany. Geophys. J. Int. 2011, 186, 359-372. [CrossRef]

22. Tajdus, A.; Cala, M.; Tajdus, K. Seismicity and Rock Burst Hazard Assessment in Fault Zones: A Case Study. Arch. Min. Sci. 2018, 63, 747-765. [CrossRef]

23. Uskov, V.A.; Eremenko, A.A.; Darbinyan, T.P.; Marysyuk, V.P. Geodynamic Hazard Assessment for Tectonic Structures in Underground Mining of North Ore Bodies in the Oktyabrsky Deposit. J. Min. Sci. 2019, 55, 77-87. [CrossRef]

24. Stewart, R.A.; Reimold, W.U.; Charlesworth, E.G.; Ortlepp, W.D. The nature of a deformation zone and fault rock related to a recent rockburst at Western Deep Levels Gold Mine, Witwatersrand Basin, South Africa. Tectonophysics 2001, 337, 173-190. [CrossRef]

25. Li, Z.; Dou, L.; Cai, W.; Wang, G.; He, J.; Gong, S.; Ding, Y. Investigation and analysis of the rock burst mechanism induced within fault-pillars. Int. J. Rock Mech. Min. Sci. 2014, 70, 192-200. [CrossRef]

26. Cai, W.; Dou, L.; Si, G.; Hu, Y. Fault-Induced Coal Burst Mechanism under Mining-Induced Static and Dynamic Stresses. Engineering 2021, 7, 687-700. [CrossRef]

27. Wang, H.; Shi, R.; Song, J.; Tian, Z.; Deng, D.; Jiang, Y. Mechanical model for the calculation of stress distribution on fault surface during the underground coal seam mining. Int. J. Rock Mech. Min. Sci. 2021, 144, 104765. [CrossRef]

28. Administration, N.M.S. Government Information Publicity. Available online: https:/ / www.chinamine-safety.gov.cn/ (accessed on 15 December 2021). 
29. Starfield, A.M.; Cundall, P.A. Towards a methodology for rock mechanics modelling. Int. J. Rock Mech. Min. Sci. Geomech. Abstr. 1988, 25, 99-106. [CrossRef]

30. Wei, C.; Zhang, C.; Canbulat, I.; Huang, W. Numerical investigation into impacts of major fault on coal burst in longwall mining-A case study. Int. J. Rock Mech. Min. Sci. 2021, 147, 104907. [CrossRef]

31. Jiang, L.; Kong, P.; Zhang, P.; Shu, J.; Wang, Q.; Chen, L.; Wu, Q. Dynamic Analysis of the Rock Burst Potential of a Longwall Panel Intersecting with a Fault. Rock Mech. Rock Eng. 2019, 53, 1737-1754. [CrossRef]

32. Bizzarri, A. Rupture speed and slip velocity: What can we learn from simulated earthquakes? Earth Planet. Sci. Lett. 2012, 317-318, 196-203. [CrossRef]

33. Sainoki, A.; Mitri, H.S. Dynamic modelling of fault-slip with Barton's shear strength model. Int. J. Rock Mech. Min. Sci. 2014, 67, 155-163. [CrossRef]

34. U.S. Geological Survey. What Is a Fault and What Are the Different Types? Available online: https://www.usgs.gov/faqs/whata-fault-and-what-are-different-types?qt-news_science_products=0\#qt-news_science_products (accessed on 10 November 2021).

35. Hu, M. Structural Geology; Petroleum Industry Press: Beijing, China, 2015.

36. Stawikowski, W. Structural Geology, 2nd ed.; Cambridge University Press: Cambridge, UK, 2017; Volume 23.

37. Chen, S.; Yin, D.; Liu, H.; Chen, B.; Jiang, N. Effects of coal's initial macro-cracks on rockburst tendency of rock-coal composite samples. R. Soc. Open Sci. 2019, 6, 181795. [CrossRef]

38. Ma, K.; Yuan, F.; Wang, H.; Zhang, Z.; Sun, X.; Peng, Y.; Wang, H. Fracture mechanism of roof key strata in Dongjiahe coal mine using microseismic moment tensor. Geomat. Nat. Hazards Risk 2021, 12, 1467-1487. [CrossRef]

39. Gao, F.; Stead, D.; Kang, H. Simulation of roof shear failure in coal mine roadways using an innovative UDEC Trigon approach. Comput. Geotech. 2014, 61, 33-41. [CrossRef]

40. Mondal, D.; Roy, P.N.S. Fractal and seismic b-value study during dynamic roof displacements (roof fall and surface blasting) for enhancing safety in the longwall coal mines. Eng. Geol. 2019, 253, 184-204. [CrossRef]

41. Wang, H.; Xue, S.; Shi, R.; Jiang, Y.; Gong, W.; Mao, L. Investigation of Fault Displacement Evolution During Extraction in Longwall Panel in an Underground Coal Mine. Rock Mech. Rock Eng. 2020, 53, 1809-1826. [CrossRef]

42. Cao, A.; Jing, G.; Dou, L.; Wu, Y.; Zhang, C. Statistical analysis of distribution patterns of coal seams in fold zones in Northwest China. Int. J. Min. Sci. Technol. 2018, 28, 819-828. [CrossRef]

43. Chen, G.; Wang, Z.; Dou, L. The Study on Prevention of Rockburst when Mining in Folding Structure Areas. In Proceedings of the Asia-Pacific Power and Energy Engineering Conference (APPEEC 2011), Wuhan, China, 25-28 March 2011.

44. Xue, Y.; Cao, Z.; Shen, W. Destabilization and energy characteristics of coal pillar in roadway driving along gob based on rockburst risk assessment. R. Soc. Open Sci. 2019, 6, 190094. [CrossRef] [PubMed]

45. Cao, A.-Y.; Dou, L.-M.; Wang, C.-B.; Yao, X.-X.; Dong, J.-Y.; Gu, Y. Microseismic Precursory Characteristics of Rock Burst Hazard in Mining Areas Near a Large Residual Coal Pillar: A Case Study from Xuzhuang Coal Mine, Xuzhou, China. Rock Mech. Rock Eng. 2016, 49, 4407-4422. [CrossRef]

46. Platform RBC Investigation Report of "2.22" Ground Pressure Impact Accident of Shandong New Julong Energy Co., LTD. Available online: https:/ / mp.weixin.qq.com/s/cZ65mX6ZYuhs5ndyN6kCrA (accessed on 21 April 2020).

47. Romashov, A.N.; Tsygankov, S.S. Generalized model of rock bursts. J. Min. Sci. 1993, 28, 420-423. [CrossRef]

48. Chen, Z.H.; Tang, C.A.; Huang, R.Q. A double rock sample model for rockbursts. Int. J. Rock Mech. Min. Sci. 1997, 34, 991-1000. [CrossRef]

49. Ma, T.-H.; Tang, C.-A.; Tang, S.-B.; Kuang, L.; Yu, Q.; Kong, D.-Q.; Zhu, X. Rockburst mechanism and prediction based on microseismic monitoring. Int. J. Rock Mech. Min. Sci. 2018, 110, 177-188. [CrossRef]

50. Cai, W.; Dou, L.; Si, G.; Cao, A.; He, J.; Liu, S. A principal component analysis/fuzzy comprehensive evaluation model for coal burst liability assessment. Int. J. Rock Mech. Min. Sci. 2016, 81, 62-69. [CrossRef]

51. Kidybiński, A. Bursting liability indices of coal. Int. J. Rock Mech. Min. Sci. Geomech. Abstr. 1981, 18, 295-304. [CrossRef]

52. Cook, N.G.W. A note on rockbursts considered as a problem of stability. J. South. Afr. Inst. Min. Metall. 1965, 65, 437-446. [CrossRef]

53. Linkov, A.M. Rockbursts and the instability of rock masses. Int. J. Rock Mech. Min. Sci. Geomech. Abstr. 1996, 33, 727-732. [CrossRef]

54. Hudson, J.A.; Crouch, S.L.; Fairhurst, C. Soft, stiff and servo-controlled testing machines: A review with reference to rock failure. Eng. Geol. 1972, 6, 155-189. [CrossRef]

55. Xu, S.; Yao, Z.; Zhou, J.; Liu, Y.; Fang, C.; Du, M. Transmittance enhancement of micro-grating structure sapphire with highrefractive index Y2O3 layer. J. Mod. Opt. 2017, 64, 777-780. [CrossRef]

56. Zhang, C.; Jin, G.; Liu, C.; Li, S.; Xue, J.; Cheng, R.; Wang, X.; Zeng, X. Prediction of rockbursts in a typical island working face of a coal mine through microseismic monitoring technology. Tunn. Undergr. Space Technol. 2021, 113, 103972. [CrossRef]

57. Yang, D.; Zhang, Y.; Chen, Z. Analysis on Catastrophe Theory during First Weighting Sliding Instability and Support Crushing of Main Roof with Large Mining Height in Shallow Coal Seam. Appl. Sci. 2020, 10, 5408. [CrossRef]

58. Zhu, G.-a.; Dou, L.-m.; Li, Z.-l.; Cai, W.; Kong, Y.; Li, J. Mining-induced stress changes and rock burst control in a variable-thickness coal seam. Arab. J. Geosci. 2016, 9, 365. [CrossRef]

59. Itasca, I. FLAC3D: Fast Lagrangian Analysis of Continua in 3 Dimension, Version Minneapolis; Itasca Consulting Group: Minneapolis, MN, USA, 2012. 
60. Karakaş, A. Practical Rock Engineering. Environ. Eng. Geosci. 2008, 14, 55-57. [CrossRef]

61. Le, T.D.; Bui, X.-N. Effect of Key Parameters on Top Coal First Caving and Roof First Weighting in Longwall Top Coal Caving: A Case Study. Int. J. Geomech. 2020, 20, 04020037. [CrossRef]

62. Cai, W.; Dou, L.; Si, G.; Cao, A.; Gong, S.; Wang, G.; Yuan, S. A new seismic-based strain energy methodology for coal burst forecasting in underground coal mines. Int. J. Rock Mech. Min. Sci. 2019, 123, 104086. [CrossRef]

63. Zubelewicz, A.; Mróz, Z. Numerical simulation of rock burst processes treated as problems of dynamic instability. Rock Mech. Rock Eng. 1983, 16, 253-274. [CrossRef]

64. Cai, W.; Bai, X.; Si, G.; Cao, W.; Gong, S.; Dou, L. A Monitoring Investigation into Rock Burst Mechanism Based on the Coupled Theory of Static and Dynamic Stresses. Rock Mech. Rock Eng. 2020, 53, 5451-5471. [CrossRef]

65. Cao, A.; Jing, G.; Ding, Y.-1.; Liu, S. Mining-induced static and dynamic loading rate effect on rock damage and acoustic emission characteristic under uniaxial compression. Saf. Sci. 2019, 116, 86-96. [CrossRef]

66. Dou, L.-m.; Mu, Z.-1.; Li, Z.-1.; Cao, A.-y.; Gong, S.-y. Research progress of monitoring, forecasting, and prevention of rockburst in underground coal mining in China. Int. J. Coal Sci. Technol. 2014, 1, 278-288. [CrossRef]

67. He, J.; Dou, L.; Gong, S.; Li, J.; Ma, Z. Rock burst assessment and prediction by dynamic and static stress analysis based on micro-seismic monitoring. Int. J. Rock Mech. Min. Sci. 2017, 93, 46-53. [CrossRef]

68. Li, Z.-l.; Dou, L.-m.; Wang, G.-f.; Cai, W.; He, J.; Ding, Y.-l. Risk evaluation of rock burst through theory of static and dynamic stresses superposition. J. Cent. South Univ. 2015, 22, 676-683. [CrossRef]

69. Wang, C.; Cao, A.; Zhang, C.; Canbulat, I. A New Method to Assess Coal Burst Risks Using Dynamic and Static Loading Analysis. Rock Mech. Rock Eng. 2019, 53, 1113-1128. [CrossRef]

70. Jaeger, J.; Cook, N.; Zimmerman, R. Fundamental of Rock Mechanics; Wiley-Blackwell: Hoboken, NJ, USA, 2007.

71. PANG, Y.; WANG, G.; LI, B. Stress path effect and instability process analysis of overlying strata in deep stopes. Chin. J. Rock Mech. Eng. 2020, 39, 682-694.

72. Bhat, H.; Dunham, E. Attenuation of Radiated Ground Motion and Stresses from Three-Dimensional Supershear Ruptures. J. Geophys. Res. (Solid Earth) 2008, 113, B08319. [CrossRef]

73. Dou, L.; He, X. Technique of classification forecasting rock burst in coal mines. J. China Univ. Min. Technol. 2007, 36, 717-722.

74. Box, G.; Hunter, S.; Hunter, W. Statistics for Experimenters: Design, Innovation, and Discovery, 2nd ed.; Wiley-Interscience: New York, NY, USA, 2005. 